Graciela Kaminsky

Saul Lizondo

Carmen M. Reinhart
Signals from some variables are better than others in predicting a currency crisis. The variables with the best track record include exponts. output, equity prices, deviations of the real exchange rate from trend, and the ratio of broad money to gross international reserves.

The World Bank

Latin America and the Caribbean Office of the Chief Economist Noyember 1997 
Policy Research Working Paper 1852

\section{Summary findings}

Kaminsky, Lizondo, and Reinhart examine the empirical evidence on currency crises and propose a specific earlywarning system.

This system involves monitoring the evolution of several indicators that tend to exhibit unusual behavior in the periods preceding a crisis. An indicator exceeding a certain threshold value should be interpreted as a warning "signal" that a currency crises may take place within the following 24 months. The threshold values are calculated to strike a balance between the risk of having many false signals and the risk of missing many crises.
Within this approach, the variables with the best track record include:

- Exports.

- Deviations of the real exchange rate from trend.

- The ratio of broad money to gross international reserves.

- Output.

- Equity prices.

The evidence does not support some of the other indicators that were considered, including imports, bank deposits, the difference between foreign and domestic real deposit interest rates, and the ratio of lending to deposit interest rates.

This paper is in part a product of the Office of the Chief Economist, Latin America and the Caribbean Region. Copies of the paper are available free from the World Bank, $1818 \mathrm{H}$ Street NW, Washington, DC 20433. Please contact Saul Lizondo, room I8-447, telephone 202-458-5431, fax 202-522-2119, Internet address slizondo@worldbank.org. November 1997. (43 pages)

The Policy Research Working Paper Series disseminates the findings of work in progress to encourage the exchange of ideas about development issues. An objective of the series is to get the findings out quickly, even if the presentations are less than fully palished. The papers carry the names of the authors and should be cited accordingly. The findings, interpretations, and conclusions expressed in this paper are entirely those of the authors. They do not necessarily represent the view of the World Bank, its Executive Directors, or the countries they represent. 


\title{
Leading Indicators of Currency Crises $^{1}$
}

\author{
Graciela Kaminsky \\ Board of Governors of the Federal Reserve System \\ Washington, D.C. 20551 \\ e-mail:mlglk99@frb.gov \\ Saul Lizondo \\ The World Bank \\ Washington, D. C. 20433 \\ e-mail:slizondo@worldbank.org \\ Carmen M. Reinhart \\ University of Maryland \\ College Park, Maryland 20742 \\ e-mail:creinhart@puafmail.umd.edu
}

'The authors thank Juan Carlos Di Tata for his help at the early stages of preparing this paper, and Ernesto Hernández-Catá for very useful suggestions and comments. They also thank Nasser Saidi and participants in seminars at the IMF, the World Bank, the CEPR Conference on Speculative Attacks on Foreign Exchange Reserves (held in Sesimbra, Portugal, April 18-19, 1997), and at the Mediterranean Economic Forum (held in Morocco, May 14-16, 1997), for useful comments, and Noah Williams and Greg Belzer for excellent research assistance. A substantial part of this paper was written while Saul Lizondo and Carmen Reinhart were at the IMF Western Hemisphere Department. 
• 


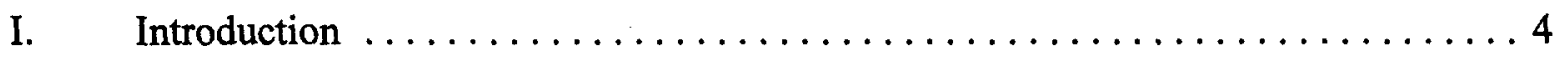

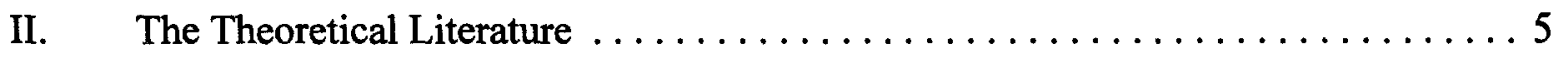

III. Indicators and Crises: The Empirical Literature $\ldots \ldots \ldots \ldots \ldots \ldots \ldots \ldots 8$

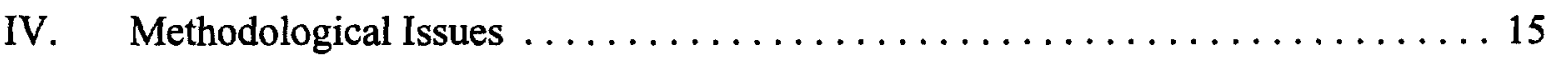

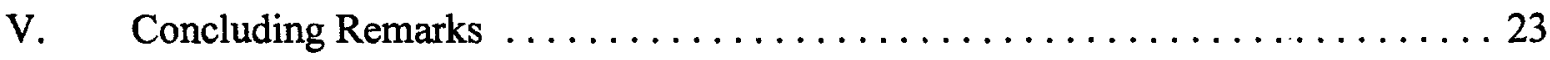

\section{Tables}

1. Indicators of Crises: A Review of the Literature $\ldots \ldots \ldots \ldots \ldots \ldots \ldots \ldots \ldots$

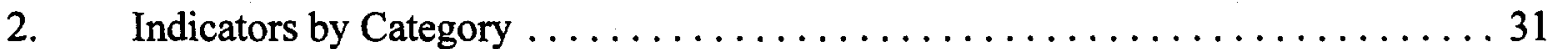

3. Indicators of Crises: What Worked Best? . . . . . . . . . . . . . . . . . 33

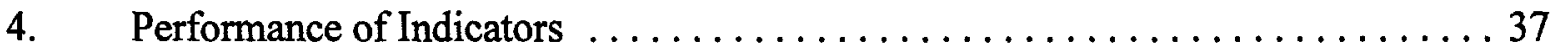

5. "Signals" Approach. Performance of Indicators $\ldots \ldots \ldots \ldots \ldots \ldots \ldots \ldots \ldots$

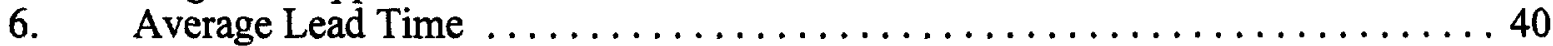

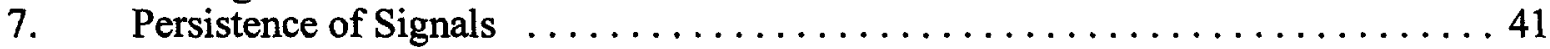

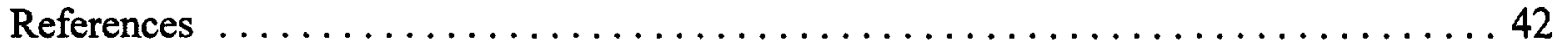




\section{INTRODUCTION}

The turbulence and collapse of the European Exchange Rate Mechanism in 1992-93 and the onset of the Mexican crisis in December 1994 have rekindled interest in both academic and policy circles in the potential causes and the symptoms of currency crises. In particular, there is a question as to whether those symptoms can be detected with sufficient advance so as to allow governments to adopt pre-emptive measures. While accurately forecasting the timing of currency crises is likely to remain an elusive goal for academics and policymakers alike, there is no question about the need to develop and improve upon a warning system that helps monitor whether a country may be slipping into a situation that is bound to end up in a crisis.

The purpose of this paper is to examine the available evidence on currency crises and to propose a specific early warning system. To this end, the paper first reviews briefly the theoretical literature on currency crises. Although there are excellent surveys available which provide comprehensive discussions of a number of theoretical issues, this paper narrows its focus to identifying the various indicators suggested by alternative explanations of currency crises. The discussion encompasses papers within the traditional approach, which stress the role played by weak economic fundamentals in inducing a currency crisis, as well as more recent papers, including those that highlight the possibility of self-fulfilling crises.

Second, the paper surveys the empirical literature to take stock of the various approaches that have been used to assess the usefulness of potential indicators of currency crises, and to identify those indicators that have been the most effective. The results indicate that an effective warning system should consider a broad variety of indicators, since currency crises seem to be usually preceded by multiple economic problems.

Third, the paper compares the relative merits of alternative approaches in providing early indications of currency crises, and based on this comparison, proposes a specific methodology for the design of an early warning system. While this methodology is novel in the literature on currency crises, it has a long history in the literature concerned with forecasting turning points in the business cycle.

The warning system proposed in the paper-the "signals" approach-essentially involves monitoring the evolution of a number of economic indicators that tend to systematically behave differently prior to a crisis. Every time that an indicator exceeds a certain threshold value, this is interpreted as a warning "signal" that a currency crisis may take place within the following 24 months. The threshold values are calculated so as to strike a balance between the risk of having many false signals (if a signal is issued at the slightest possibility of a crisis) and the risk of missing many crises (if the signal is issued only when the evidence is overwhelming). Also, since the group of indicators that are issuing signals would be identified, this helps provide information about the source(s) of the problems that underlie the probability of a crisis.

The variables that have the best track record in anticipating crises in the context of the "signals" approach, include: output, exports, deviations of the real exchange rate from trend, equity prices, and the ratio of broad money to gross international reserves. Furthermore, on average, these and other indicators provide signals with sufficient advance so as to allow for pre-emptive policy measures. The evidence does not provide support for some of the other indicators that were considered, including imports, the differential between foreign and 
domestic real deposit interest rates, the ratio of lending to deposit interest rates, and bank deposits.

The rest of the paper is organized as follows. Section II briefly summarizes the theoretical literature on currency crises, while Section III presents a more detailed discussion of the empirical literature, describing the various methodologies and variables that have been used to assess the probability of a crisis, and highlighting those variables that have been identified as the most useful indicators. Section IV discusses the relative merits of alternative methodologies, and, on this basis, proposes an specific procedure to design of an early warning system. It also uses this methodology to evaluate the predictive ability of fifteen macroeconomic and financial variables. Section V presents some concluding remarks.

\section{THE TheORETICAL LITERATURE}

This section summarizes the main explanations for speculative attacks and balance-ofpayments crises that have been presented in the theoretical literature. The aim is to provide some background as to why a variety of indicators have been used in empirical work on crises. ${ }^{2}$ The theoretical literature on balance-of-payments crises has flourished following Krugman's seminal paper of 1979. Initially, this literature stressed that crises were caused by weak "economic fundamentals," such as excessively expansionary fiscal and monetary policies, which resulted in a persistent loss of international reserves that ultimately forced the authorities to abandon the parity. More recently, however, some papers have argued that the authorities may decide to abandon the parity for reasons other than a depletion of official international reserves. Instead, they may be concerned about the adverse consequences of policies needed to maintain the parity (such as higher interest rates) on other key economic variables (such as the level of employment).

Recent models also have shown that a crisis may develop without a significant change in the fundamentals. In these models, economic policies are not predetermined but respond to changes in the economy, and economic agents take this relationship into account in forming their expectations. This set of assumptions opens the possibility for multiple equilibria and self-fulfilling crises. These recent theoretical developments accord a smaller role to fundamentals in generating balance-of-payments crises, but they also have highlighted the importance that other variables may have in helping to predict those crises.

\section{A. The Traditional Approach}

Krugman's (1979) model shows that, under a fixed exchange rate, domestic credit expansion in excess of money demand growth leads to a gradual but persistent loss of international reserves and, ultimately, to a speculative attack on the currency. This attack immediately depletes reserves and forces the authorities to abandon the parity. The process ends with an attack because economic agents understand that the fixed exchange rate regime ultimately will collapse, and that in the absence of an attack they would suffer a capital loss on their holdings of domestic money. This model suggests that the period preceding a currency crisis

${ }^{2}$ For detailed surveys of the theoretical literature see Agenor, Bhandari, and Flood (1992), Blackburn and Sola (1993), and Garber and Svensson (1994). Gupta (1996) presents a short survey of theoretical and empirical results on currency and banking crises. 
would be characterized by a gradual but persistent decline in international reserves and a rapid growth of domestic credit relative to the demand for money. Also, to the extent that excessive money creation may result from the need to finance the public sector, fiscal imbalances and credit to the public sector also could serve as indicators of a looming crisis.

A number of papers have extended Krugman's basic model in various directions. ${ }^{3}$ Some of these extensions have shown that speculative attacks would generally be preceded by a real appreciation of the currency and a deterioration of the trade balance. These results have been derived from models in which expansionary fiscal and credit policies lead to higher demand for traded goods (which causes a deterioration of the trade balance) and nontraded goods (which causes an increase in the relative price of these goods, and thus a real appreciation of the currency). They also follow from models in which expectations of a future crisis lead to an increase in nominal wages which, in the presence of sticky prices, results in higher real wages and lower competitiveness. Also, models that introduce uncertainty about credit policy or about the level of reserves losses that the authorities are willing to sustain to defend the parity, show that domestic interest rates would increase as a crisis becomes more likely. Thus, these models suggest that the evolution of the real exchange rate, the trade or current account balance, real wages, and domestic interest rates, could be used as leading indicators of crises.

\section{B. Recent Models}

While the traditional approach stresses the role played by declining international reserves in triggering the collapse of a fixed exchange rate, some recent models have suggested that the decision to abandon the parity may stem from the authorities' concern about the evolution of other key economic variables-suggesting that yet another family of variables could be useful in helping predict currency crises.

For instance, Ozkan and Sutherland (1995) present a model in which the authorities' objective function depends positively on certain benefits derived from keeping a fixed nominal exchange rate (such as enhanced credibility in their efforts to reduce inflation) and negatively on the deviations of output from a certain target level. Under a fixed exchange rate, increases in foreign interest rates lead to higher domestic interest rates and lower levels of output, making it more costly for the authorities to maintain the parity. Once foreign interest rates exceed some critical level, the cost of keeping the exchange rate fixed surpasses the benefits, and the authorities abandon the parity. Based on this model, therefore, the evolution of output and domestic and foreign interest rates may be useful as indicators of currency crises.

More generally, this approach suggests that a variety of factors which may affect the authorities' objective function could be used as leading indicators of currency crises. For instance, an increase in domestic interest rates needed to maintain a fixed exchange rate may

${ }^{3}$ References to these papers can be found in the surveys mentioned above. In addition to those described in the main text, the extensions include post-collapse exchange systems other than a permanent float (such as fixed, crawling, and transitory float), the possibility of foreign borrowing, capital controls, imperfect asset substitutability, and speculative attacks in which the domestic currency is under buying rather than selling pressure. 
result in higher financing costs for the government. To the extent that the authorities are concerned about the fiscal consequences of their exchange rate policy, the decision to abandon the parity may depend on the stock of public debt. Also, higher interest rates may weaken the banking system, and the authorities may prefer to devalue rather than incur the cost of a bailout that could result from an explicit or implicit official guarantee on the banking system liabilities. ${ }^{4}$ Therefore, the presence of banking problems (say, as reflected in the relative price of bank stocks, the proportion of non-performing loans, central bank credit to banks, or a large decline in deposits) could also indicate a higher likelihood of a crisis. Leading indicators may also include political variables.

Recent models also have suggested that crises may develop without any noticeable change in economic fundamentals. These models emphasize that the contingent nature of economic policies may give rise to multiple equilibria and generate self-fulfilling crises. A crucial assumption in these models is that economic policies are not predetermined but respond instead to changes in the economy and that economic agents take this relationship into account in forming their expectations. At the same time, the expectations and actions of economic agents affect some variables to which economic policies respond. This circularity creates the possibility for multiple equilibria and the economy may move from one equilibrium to another without a change in the fundamentals. Thus, the economy may be initially in an equilibrium consistent with a fixed exchange rate, but a sudden worsening of expectations may lead to changes in policies that result in a collapse of the exchange regime, thereby validating agents' expectations.

In Obstfeld (1994), the expectation of a collapse leads to higher wages and lower employment, which prompts the government to abandon the parity out of concern for output. In a second model, expectations of a collapse lead to higher interest rates, prompting the government to abandon the parity out of concern for the increased cost of servicing the public debt. As indicated in Obstfeld (1996), the increase in interest rates also could work through other channels that may affect the government's objective function. For instance, an increase in interest rates may increase the probability of a banking crisis and the associated fiscal costs of a bailout.

The main implication of models with self-fulfilling crises regarding the possibility of predicting crises is a negative one. This type of model suggests that it may be difficult to find a tight relationship between fundamentals and crises, as sometimes crises may take place without a previous significant change in fundamentals. Finally, some recent papers have focused on contagion effects as the spark of a balance-of-payments crisis. For instance, Gerlach and Smets (1994) present a model in which the devaluation by one country leads its trading partners to devalue in order to avoid a loss of competitiveness. ${ }^{5}$ Contagion effects also may arise if investors pay little heed to countries' economic fundamentals, and thus do

${ }^{4}$ Velasco (1987) and Calvo (1995) link balance of payments crises to problems in the banking sector.

${ }^{5}$ As the authors indicate, the same effect could be derived in a model with multiple equilibria, in which the devaluation by a trade partner serves to coordinate a worsening of expectations about the domestic economy and generate a self-fulfilling speculative attack. 
not discriminate properly among countries. ${ }^{6}$ If contagion effects are present, a crisis in a neighboring country may be an indicator of a future domestic crisis.

\section{INDICATORS AND CRISES: THE EMPIRICAL LITERATURE}

This section begins with a description of the various methodologies and variables that have been used in the empirical literature to characterize the period preceding currency crises and to assess the probability of such crises. It then proceeds to narrow the list of potential leading indicators to those variables which appear to have worked best, and concludes by highlighting some of the key findings of this literature.

\section{A. Alternative Approaches: A Description}

Table 1 provides a summary of 25 selected empirical studies on currency crises. The first column lists the study, the second describes the sample periods and the periodicity of the data, and the third provides information on the countries covered and the type of episode examined. The fourth column lists the economic and political variables that have been used as indicators, and the last column sketches certain features of the methodology used and the principal goal of the study in question.

These studies provide information on the numerous and varied experiences with currency crises. They examine sample periods that run from the early 1950 s to the mid 1990 s, and cover both industrial and developing countries, although with more emphasis on the latter. About half of the studies use monthly data, with the rest using annual or quarterly data, or data of varied periodicity. Most of the papers examine the experience of various countries and study several crisis episodes; only a few papers focus on a single country.

The studies also vary with respect to how a "crisis" is defined. Most of the studies focus exclusively on devaluation episodes. Some of them examine large and infrequent devaluations, ${ }^{7}$ while others include in their sample small and frequent devaluations that may not fit the mold of a full-blown currency crisis. ${ }^{8} \mathrm{~A}$ few studies adopt a broader definition of crises. They include, in addition to devaluations, episodes of unsuccessful speculative attacks; i.e., attacks that were averted without a devaluation, but at the cost of a large increase in domestic interest rates and/or a sizable loss of international reserves. ${ }^{9}$

${ }^{6}$ Calvo and Reinhart (1996) discuss these and other channels for the transmission of contagion effects.

${ }^{7}$ For instance, Edwards (1989), Edwards and Montiel (1989), Edwards and Santaella (1993), and Frankel and Rose (1996).

${ }^{8}$ For instance, Collins (1995), Flood and Marion (1995), Kamin (1988), and Klein and Marion (1994).

${ }^{9}$ This group includes Eichengreen, Rose, and Wyplosz (1995), Kaminsky and Reinhart (1996), and Sachs, Tornell and Velasco (1996). 
Regarding the methodology used, the various papers can be grouped into four broad categories. A first group of papers provide only a qualitative discussion of the causes and developments leading to the currency crises. These papers often stress the evolution of one or more indicators, but no formal tests are conducted to evaluate the usefulness of the various indicators in predicting crises. ${ }^{10}$

A second group of papers examine the stylized facts of the period leading up to and immediately following the currency crisis. Sometimes the pre-crisis behavior of a variable is compared to its behavior during "tranquil" or non-crises periods for the same group of countries. ${ }^{11}$ In other instances, the control group is composed of countries where no crisis occurred. ${ }^{12}$ Parametric and nonparametric tests are used to assess whether there are systematic differences between the pre-crisis episodes and the control group. These tests can be useful in narrowing the list of potential indicators, as not all the variables included in the analysis ended up showing "abnormal" behavior in advance of crises.

A third group of papers estimate the probability of devaluation one or several periods ahead, usually on the basis of an explicit theoretical model, along the lines pioneered by Blanco and Garber (1986) in their discussion of the Mexican crisis of the early 1980s. These papers include individual country studies and multi-country panel studies. ${ }^{13}$ Some of these papers also have attempted to shed light on the variables that determine the size of the devaluation. ${ }^{14}$ In a related spirit, Sachs, Tornell, and Velasco (1996) seek to identify those macroeconomic variables that can help explain which countries were vulnerable to "contagion effects" following the Mexican crisis of December 1994. The results from this group of studies also help to narrow the list of useful indicators, as not all the variables included turned out to be statistically significant in the logit (or probit) estimation exercises typically undertaken.

A fourth type of methodology is used in Kaminsky and Reinhart (1996). This paper presents a nonparametric approach to evaluate the usefulness of several variables in signaling an

${ }^{10}$ For instance, Dornbusch, Goldfajn, and Valdes (1995) stress an overvalued exchange rate; Goldstein (1996) emphasize a boom in bank lending; Krugman (1996) focuses on the high debt levels; while Milesi-Ferretti and Razin (1995) highlight the role of servicing costs (adjusted for growth and changes in the real exchange rate).

${ }^{11}$ For example, Eichengreen, Rose, and Wyplosz (1995), Frankel and Rose (1996), and Moreno (1995).

${ }^{12}$ See, for instance, Edwards (1989), Edwards and Santaella (1993), and Kamin (1988).

${ }^{13}$ Individual countries are discussed in Cumby and van Wijnbergen (1989), Kaminsky and Leiderman (1995), Otker and Pazarbasioglu (1994 and 1995), among others. Multicountry studies include Collins (1995), Edin and Vredin (1993), Edwards (1989), Eichengreen, Wyplosz and Rose (1995), Frankel and Rose (1996), and Klein and Marion (1994).

${ }^{14}$ For instance, Bilson (1978), Edin and Vredin (1993) and Flood and Marion (1995). 
impending crisis. It can be interpreted as an extension of the methodology that compares the behavior of variables in periods preceding crises with that in a control group. This approach involves monitoring the evolution of a number of economic variables whose behavior usually departs from "normal" in the period preceding a currency crisis. Deviations of these variables from their "normal" levels beyond a certain threshold value, are taken as warning "signals" of a currency crisis within a specified period of time. Based on the track record of the various indicators, it is possible to assess their individual and combined ability to predict crises. This approach is explained in detail in Section IV.

\section{B. The Indicators}

The studies reviewed in this paper used a large variety of indicators. Table 2 presents a list of the 103 indicators used, grouped into six broad categories and some sub-categories, ${ }^{15}$ including: (1) the external sector; (2) the financial sector; (3) the real sector; (4) the public finances; (5) institutional and structural variables; and (6) political variables. The indicators of the external sector were, in turn, classified into those related to the capital account, the external debt profile, the current account, and international (or foreign) variables. The indicators of the financial sector were split into those that could be associated with financial liberalization, and other indicators.

It is important to note that many of the indicators listed in Table 2 are transformations of the same variable. For instance, several variables are expressed alternatively in levels or in rates of change; sometimes on their own and other times relative to some standard (such as the same variable in a trading partner). For instance, the real exchange rate is expressed, alternatively, on a bilateral basis or in real effective terms; sometimes in levels and other times as deviations from either purchasing power parity, a time trend, or its historical average. The use of scale factors also varies across studies. For example, alternative scale factors used for international reserves include GDP, base money, M1, and the level of imports.

After consolidating the different transformations of the same variable, the main indicators used in empirical work, classified by category, are as follows:

- Capital account: international reserves, capital flows, short-term capital flows, foreign direct investment, and the differential between domestic and foreign interest rates.

- Debt profile: public foreign debt, total foreign debt, short-term debt, share of debt classified by type of creditor and by interest structure, debt service, and foreign aid.

- Current account: the real exchange rate, the current account balance, the trade balance, exports, imports, the terms of trade, the price of exports, savings and investment.

\footnotetext{
${ }^{15}$ Although the proper classification for most indicators is unambiguous, that of other indicators is to some extent arbitrary as they could have been properly classified in more than one category.
} 
- International variables: foreign real GDP growth, interest rates, and price level.

- Financial liberalization: credit growth, the change in the money multiplier, real interest rates, and the spread between bank lending and deposit interest rates.

- Other financial variables: central bank credit to the banking system, the gap between money demand and supply, money growth, bond yields, domestic inflation, the "shadow" exchange rate, the parallel market exchange rate premium, the central exchange rate parity, the position of the exchange rate within the official band, and $\mathrm{M} 2$ /international reserves.

- Real sector: real GDP growth, the output gap, employment/unemployment, wages, and changes in stock prices.

- Fiscal variables: the fiscal deficit, government consumption, and credit to the public sector.

- Institutional/structural factors: openness, trade concentration, and dummies for multiple exchange rates, exchange controls, duration of the fixed exchange rate periods, financial liberalization, banking crises, past foreign exchange market crises, and past foreign exchange market events. ${ }^{16}$

- Political variables: dummies for elections, incumbent electoral victory or loss, change of government, legal executive transfer, illegal executive transfer, left-wing government, and new finance minister; also, degree of political instability (qualitative variable based on judgement).

\section{What Worked Best?}

This section describes the criteria used to identify those indicators that have proven to be most useful in predicting crises. The idea is to select the indicators whose contribution to the prediction of crises was found to be statistically significant, based on the results presented in the original papers. This necessarily excludes from consideration those variables that were used only in papers that provide a qualitative rather than a formal quantitative assessment of indicators. Therefore, the discussion that follows focuses on papers where: (a) the indicators were used to estimate the probability of a crisis; or (b) the indicators' pre-crisis behavior was systematically compared with its behavior in a control group (comprising either the same countries during "tranquil" times or non-crises countries); or (c) the indicators' ability for signaling future crises was systematically assessed in quantitative terms. Also, the discussion focuses primarily on papers that examine the experience of various countries, as their findings are more likely to be suitable for generalization than the findings of papers that study a single experience.

${ }^{16}$ Foreign exchange market "events" include significant changes in exchange arrangements (such as devaluations, revaluations, decisions to float, and widening of exchange rate bands); "crises" overlap with events, but include unsuccessful speculative attacks and excludes changes in exchange arrangements not associated with exchange market pressures. 
Table 3 identifies the indicators that worked best by any of the above criteria in the subset of 14 papers that comply with the criteria mentioned above. For those papers that perform the pre-crisis/control-group comparison, the second column of the table lists those variables for which the difference in behavior was significant (at the 10 percent level or higher) in at least one of the test performed in the paper. Notice, however, that abnormal behavior in the precrisis period is a necessary but not a sufficient condition for an indicator to be useful, as some of the variables that pass the univariate tests are not significant in multivariate regressions.

For the papers that estimate the one-period (or several periods) ahead probability of a crisis, the second column of Table 3 shows the variables that were statistically significant (at the 10 percent level or higher) in the logit or probit regressions. This winnows the list of indicators considerable. For instance, Frankel and Rose (1996) initially considered 16 possible indicators, but only 7 of them turned out to be statistically significant. The results presented in Otker and Pazarbasioglu (1994) show considerable cross-country variation regarding the variables that survived this test.

In the case of the variables used in Kaminsky and Reinhart (1996), the second column in Table 3 lists those whose behavior in the period leading to a crisis was significantly different from their behavior during "tranquil" periods. Within this approach, these are the variables that would be expected to issue a relatively large number of good signals (signals that are followed by a crisis) and few false signals (signals that are not followed by a crisis). The criterium was to include in Table 3 those variables that had an (adjusted) noise-to-signal ratios lower than unity. ${ }^{17}$ The (adjusted) noise-to-signal ratio for these variables are presented in Table 5, Section IV, where the "signals" approach is explained in detail.

\section{Some General Results}

Table 4 shows the various indicators (after consolidating the different transformations of the same variable) included in these studies. For each indicator, Table 4 shows the number of studies that tested the significance of the indictor, as well as the number of studies in which the indicator was found to be significant in at least one of the tests conducted.

The comparison of results across the various papers considered above does not provide a clear-cut answer concerning the usefulness of each of the potential indicators of currency crisis. This is not surprising given the number of relevant factors that differ significantly among those papers, such as the set of variables simultaneously included in the tests, the way of measuring those variables, the periodicity of the data, the estimation technique, etc. Also, as noted above, some variables that are significant in univariate tests are not significant in multivariate tests.

Despite these difficulties, a number of conclusions can be derived from the tally shown in Table 4:

${ }^{17}$ The calculation of this ratio is described in detail below. Essentially, it is the ratio of false signals (noise) to good signals, adjusted to take into account that in the sample used in the paper the number of opportunities for false and for good signals differ. 
The first general conclusion is that an effective warning system should consider a broad variety of indicators; currency crises seem to be usually preceded by multiple economic, and sometimes political, problems. The evidence reviewed here points to the presence of both domestic and external imbalances which span both the real side of the economy and the domestic financial sector.

Second, those individual variables that receive ample support as useful indicators of currency crises include international reserves, the real exchange rate, credit growth, credit to the public sector, and domestic inflation. The results also provide support for the trade balance, export performance, money growth, M2/international reserves, real GDP growth, and the fiscal deficit.

Third, only tentative čnclusions can be drawn regarding the other indicators, primarily because they have been included in only one or two of the studies under review. Subject to this caveat, the results suggest that several foreign, political, institutional, and financial variables (other than those mentioned above), also have some predictive power in anticipating currency crises.

Fourth, the variables associated with the external debt profile did not fare well. Also, contrary to expectations, the current account balance did not receive much support as a useful indicator of crises. This may be because the information provided by the behavior of the current account balance to some extent already may have been reflected in the evolution of the real exchange rate. In most of the studies in which the effect of the current account balance was found to be non-significant, the real exchange also was included in the test, and had a significant effect.

The issue of the empirical relevance of self-fulfilling crises is subject to debate. A number of findings in Eichengreen, Rose and Wyplosz (1995) have been interpreted as evidence of the existence of self-fulfilling crises. Those findings include: (1) many crises did not seem to be linked to the driving forces emphasized by models in the traditional approach; (2) some crises that were not preceded, and were not followed, by a weakening of policies, so it is not possible to argue that those crises were produced by economic agents correctly anticipating a future deterioration in policies; and (3) those crises that occurred without obvious causes were usually not anticipated by the market and not reflected in advance in interest rate differentials.

Krugman (1996) has argued, however, that the findings described in (1), (2), and (3) above do not constitute evidence in favor of self-fulfilling crises. The argument is as follows. Point (1) is evidence against models in the traditional approach and in favor of recent models in which the authorities devalue because of concern for variables other than international reserves, but it is not evidence in favor of self-fulfilling crises. Point (2) provides evidence against models with self-fulfilling crises because it is precisely in those models that policies are assumed to respond to private sector actions, including the attack on the currency. Finally, point ( 3 ) is not necessarily evidence in favor of self-fulfilling crises because, the market should anticipate the possibility of crises, even those of the self-fulfilling type. It 
would be more reasonable to interpret the evidence in (3) as reflecting some myopia on the part of investors. ${ }^{18}$

\section{METHOdological ISSUES}

This section discusses the relative merits of the alternative approaches used to assess the probability of a currency crisis, and proceeds to describe in some detail a methodology that serves as the basis for the warning system proposed in this paper.

\section{A. Alternative Approaches: An Evaluation}

The studies reviewed above have used essentially two alternative methodologies that could serve as the basis for an early warning system of currency crises. The most commonly used approach has been to estimate the one-step (or k-step) ahead probability of devaluation in the context of a multivariate logit or probit model. While the explanatory variables have been quite varied, the estimation technique has been quite uniform. ${ }^{19}$ The second approach has been to compare the behavior of selected variables in the period preceding crises with their behavior in a control group, and to identify those variables whose distinctive behavior could be used to help assess the likelihood of a crisis. The particular variant of this approach presented in Kaminsky and Reinhart (1996) has progressed to construct a warning system based on signals issued by those selected variables.

The methodology that estimates the one-step (or k-step) ahead probability of devaluation has the advantage that it summarizes the information about the likelihood of a crisis in one useful number, the probability of devaluation. Also, as this approach considers all the variables simultaneously, and it disregards those variables that do not contribute information that is independent from that provided by other variables already included in the analysis.

This methodology, however, also has some important limitations. First, the methodology does not provide a metric for ranking the indicators according to their ability to accurately predict crises and avoid false signals, since a variable either enters the regression significantly or it does not. While measures of statistical significance can help pinpoint which are the more reliable indicators, they provide no information on whether the relative strength of that indicator lies in accurately calling a high proportion of crises at the expense of sending numerous false alarms, or instead missing a large share of crises but seldom sending false

${ }^{18} \mathrm{Jeanne}(1995)$ takes a different approach to test for the existence of self-fulfilling crises using data on the French Franc/deutsche Mark exchange rate for the period 1992-1993, and concludes that in fact the estimated relationship has the shape needed to produce multiple equilibria and self-fulfilling crises. These findings, however, are not entirely persuasive, mainly because of the way in which the fundamentals are treated in the estimation.

${ }^{19}$ Sachs, Tornell, and Velasco (1996) use an alternative strategy, but they examine the different, although related, issues of which countries were vulnerable on the wake of the Mexican crisis and what accounted for their vulnerability. 
alarms. Furthermore, the nonlinear nature of these models make it difficult to assess the marginal contribution of an indicator to the probability of a crisis. ${ }^{20}$

Second, this method does not provide a transparent reading of where and how widespread the macroeconomic problems are. Within this approach, it is difficult to judge which of the variables is "out-of-line," making it less-than-ideally suited for the purpose surveillance and pre-emptive action.

In contrast, the approach in Kaminsky and Reinhart (1996) tallies the performance of individual indicators, and thus provides information on the source and breadth of the problems that underline the probability of a crisis. Furthermore, as explained below, within this approach it is also possible to estimate the probability of a crisis conditional on the signals issued by the various indicators. This conditional probability of crisis will depend directly on the reliability of the indicators that are sending the signals. For instance, if at any point in time six indicators are sending signals, the probability of a crisis conditional on those signals will be higher if the signals are coming from the six best indicators than if they are coming from a less reliable group of indicators.

Based on these considerations, the "signals" approach seems to be better suited to serve as the basis for the design of an early warning system. The methodology employed, while not previously applied to analyze currency crises, has a long history in the literature that evaluates the ability of macroeconomic and financial time series to predict business cycle tuning points. This methodology is described in detail below.

\section{B. The "Signals" Approach}

This section describes the "signals" approach as well as some of the empirical results obtained by using this approach. It summarizes the discussion in Kaminsky and Reinhart (1996), who examine 76 currency crises from a sample of 15 developing and 5 industrial countries during 1970-1995. It also expands the analysis presented in that paper by ranking the indicators by three alternative metrics which include: calculating the probability of a crisis conditional on a signal from that indicator; the average number of months prior to the crisis in which the first signal is issued; and the persistence of signals ahead of crises.

\section{Definitions}

As mentioned above, this approach involves monitoring the evolution of a number of economic variables. When one of these variables deviates from its "normal" level beyond a certain "threshold" value, this is taken as a warning signal about a possible currency crisis within a specified period of time. However, in order to make the approach operational, a number of terms must be defined.

Crisis: A crisis is defined as a situation in which an attack on the currency leads to a sharp depreciation of the currency, a large decline in international reserves, or a combination of the two. A crisis so defined includes both successful and unsuccessful attacks on the currency.

\footnotetext{
${ }^{20}$ Note that this marginal contribution is not independent of the other explanatory variables in the regression.
} 
The definition is also comprehensive enough to include not only currency attacks under a fixed exchange rate but also attacks under other exchange rate regimes. For example, an attack could force a large devaluation beyond the established rules of a prevailing crawlingpeg regime or exchange rate band.

For each country, crises are identified (ex-post) by the behavior of an index of "exchange market pressure." This index is a weighted average of monthly percentage changes in the exchange rate (defined as units of domestic currency per U.S. dollar or per deustche mark, depending on which is the relevant) and (the negative of) monthly percentage changes in gross international reserves (measured in U.S. dollars). ${ }^{21}$ The weights are chosen so that the two components of the index have the same conditional variance. As the index increases with a depreciation of the currency and with a loss of international reserves, an increase in the index reflects stronger selling pressure on the domestic currency.

In the empirical application, a crisis is identified by the behavior of the exchange market pressure index. Periods in which the index is above its mean by more than three standard deviations are defined as crises. ${ }^{22}$ The appropriateness of this operational definition was checked by examining developments in foreign exchange markets during the periods identified as crises. In many cases, these periods included also other signs of turbulence such as the introduction of exchange controls, the closing of the exchange markets, a change in the exchange rate regime, etc.

Indicators: The choice of indicators was dictated by theoretical considerations and by the availability of information on a monthly basis. They include: (1) international reserves (in U.S. dollars); (2) imports (in U.S. dollars); (3) exports (in U.S. dollars); (4) the terms of trade (defined as the unit value of exports over the unit value of imports); (5) deviations of the real

${ }^{21}$ Eichengreen, Rose, and Wyplosz (1995) also include the level of domestic interest rates in their index of exchange market pressure, because the authorities could also resort to increases in interest rates to defend the currency. However, this variable was not included in the index used in Kaminsky and Reinhart (1996) because the data on market-determined interest rates in developing countries do not span the entire sample period.

${ }^{22}$ For countries in the sample that, at different times, experienced very high inflation, the criterium for identifying crises was modified. If a single level of the index had been used to identify crises in these countries, sizable devaluations and reserve losses in the more moderate inflation periods would not be identified as crises because the historic mean and variance would be distorted by the high-inflation episodes. To avoid this problem, the sample was divided according to whether inflation in the previous six months was higher than 150 percent, and a different level of the index (based on a different mean and variance) was used to identify crises in each sub-sample. While this method is admittedly arbitrary, the cataloging of crises obtained by this method follows closely the chronology of currency market disruptions described in numerous articles. 
exchange rate from trend (in percentage terms); ${ }^{23}$ (6) the differential between foreign (U.S. or German) and domestic real interest rates on deposits (monthly rates, deflated using consumer prices and measured in percentage points); (7) "excess" real M1 balances; ${ }^{24}(8)$ the money multiplier (of M2); (9) the ratio of domestic credit to GDP; (10) the real interest rate on deposits (monthly rates, deflated using consumer prices and measured in percentage points); (11) the ratio of (nominal) lending to deposit interest rates; ${ }^{25}(12)$ the stock of commercial banks deposits (in nominal terms); (13) the ratio of broad money (converted into foreign currency) to gross international reserves; (14) an index of output; and (15) an index of equity prices (measured in U.S. dollars).

For all these variables (with the exception of the deviation of the real exchange rate from trend, the "excess" of real M1 balances, and the three variables based on interest rates), the indicator on a given month was defined as the percentage change in the level of the variable with respect to its level a year earlier. Filtering the data by using the 12-month percentage change ensures that the units are comparable across countries and that the transformed variables are stationary, with well-defined moments, and free from seasonal effects.

Signaling horizon: This is the period within which the indicators would be expected to have an ability for anticipating crises. This period was defined a-priori as 24 months. Thus, a signal that is followed by a crisis within 24 months is called a good signal, while a signal not followed by a crisis within that interval of time is called a false signal, or noise.

Signals and thresholds: An indicator is said to issue a signal whenever it departs from its mean beyond a given threshold level. Threshold levels are chosen so as to strike a balance between the risks of having many false signals (which would happen if a signal is issued at the slightest possibility of a crisis) and the risk of missing many crises (which would happen if the signal is issued only when the evidence is overwhelming).

For each of the indicators, the following procedure was used to obtain the "optimal" set of country-specific thresholds that were employed in the empirical application. Thresholds were defined in relation to percentiles of the distribution of observations of the indicator. For example, a possible set of country-specific thresholds for the rate of growth of imports would be the set of rates of growth (one per country) that would leave 10 percent of the observations

${ }^{23}$ The real exchange rate is defined on a bilateral basis with respect to the German mark for the European countries in the sample, and with respect to the U.S. dollar for all the other countries. The real exchange rate index is defined such that an increase in the index denotes a real depreciation.

${ }^{24}$ Defined as the percentage difference between actual M1 in real terms and an estimated demand for M1; the latter is assumed to be a function of real GDP, domestic inflation, and a time trend.

${ }^{25}$ This definition of the spread between lending and deposit rates is preferable to using the difference between (nominal) lending and deposit rates, because this difference is affected by inflation and thus the measure would be distorted in the periods of high inflation. An alternative would have been to use the difference between real lending and deposit rates. 
(on the rate of growth of imports) above the threshold for each country. Notice that while the percentile used as reference ( 10 percent) is uniform across countries, the corresponding country-specific thresholds (the rates of growth of imports associated with that 10 percent) would most likely differ. This procedure was repeated using a grid of reference percentiles between 10 percent and 20 percent, and the "optimal" set of thresholds was defined as the one that minimized the noise-to-signal ratio; i.e., the ratio of false signals to good signals. ${ }^{26}$

\section{Empirical results}

The effectiveness of the signals approach can be examined at the level of individual indicators (the extent to which a given indicator is useful in anticipating crises) and at the level of a set of indicators (the extent to which a given group of indicators taken together is useful in anticipating crises). The discussion below examines the effectiveness of individual indicators. It extends some of the analysis presented in Kaminsky and Reinhart (1996) by ranking the various indicators according to their forecasting ability, and by examining the lead time and persistence of their signals. An important area for future work would be to combine the information on the various indicators to estimate the probability of a crisis conditional on simultaneous signals from any set of indicators.

In order to examine the effectiveness of individual indicators, it would be useful to consider the performance of each indicator in terms of the following matrix:

\begin{tabular}{|l|c|c|}
\hline & Crisis (within 24 months) & No crisis (within 24 months) \\
\hline Signal was issued & A & B \\
\hline No signal was issued & C & D \\
\hline
\end{tabular}

In this matrix, $\mathrm{A}$ is the number of months in which the indicator issued a good signal, $\mathrm{B}$ is the number of months in which the indicator issued a bad signal or "noise," $\mathrm{C}$ is the number of months in which the indicator failed to issue a signal (which would have been a good signal), and $D$ is the number of months in which the indicator refrained from issuing a signal (which would have been a bad signal). A perfect indicator would only produce observations that belong to the north-west and south-east cells of this matrix. It would issue a signal in every month that is to be followed by a crisis (within the next 24 months), so that $\mathrm{A}>0$ and $\mathrm{C}=0$, and it would refrain from issuing a signal in every month that is not to be followed by a crisis (within the next 24 months), so that $B=0$ and $D>0$. Of course, in practice, none of the indicators fit the profile of a perfect indicator. However, the matrix above will be a useful reference to assess how close or how far is each indicator from that profile.

${ }^{26}$ For variables such as international reserves, exports, the terms of trade, deviations of the real exchange rate from trend, commercial bank deposits, output, and the stock market index, for which a decline in the indicator increases the probability of a crisis, the threshold is below the mean of the indicator. For the other variables, the threshold is above the mean of the indicator. 
Information on the performance of individual indicators is presented in Table 5. For each indicator, the first column shows the number of crises for which data on the indicator are available. The number of crises range from 33 to 72 , with an average of 61 crises per indicator. The second column shows the percentage of crises correctly called, defined as the number of crises for which the indicator issued at least one signal in the previous 24 months (expressed as a percentage of the total number of crises for which data on the indicator are available). Virtually every indicator called correctly at least half of the crises in their respective samples. In average, the various indicators called correctly 70 percent of the crises.

The third column of Table 5 shows an alternative measure of the tendency of individual indicators to issue good signals. It shows the number of good signals issued by the indicator, expressed as a percentage of the number of months in which good signals could have been issued $(\mathrm{A} /(\mathrm{A}+\mathrm{C})$ in terms of the above matrix). While obtaining 100 percent in the second column of Table 5 would require that at least one signal be issued within the 24 months prior to each crisis, a 100 percent in the third column would require that a signal be issued every month during the $\mathbf{2 4}$ months prior to each crisis. In terms of the results in the third column, the real exchange rate is the indicator that issued the highest percentage of possible good signals ( 25 percent), while imports issued the lowest percentage of possible good signals ( 9 percent).

The fourth column of Table 5 measures the performance of individual indicators regarding sending bad signals. It shows the number of bad signals issued by the indicator, expressed as a percentage of number of months in which bad signals could have been issued $(B /(B+D)$ in terms of the above matrix). Other things equal, the lower the number in this column the better is the indicator. The real exchange rate, once again, shows the best performance (issuing only 5 percent of possible bad signals), while the ratio of lending to deposit interest rate shows the poorest performance (issuing 22 percent of possible bad signals).

The information about the indicators' ability to issue good signals and to avoid bad signals can be combined into a measure of the "noisiness" of the indicators. The fifth column of Table 5 shows the "adjusted" noise-to-signal ratio; this ratio is obtained by dividing false signals measured as a proportion of months in which false signals could have been issued, by good signals measured as a proportion of months in which good signals could have been issued $([\mathrm{B} /(\mathrm{B}+\mathrm{D})] /[\mathrm{A} /(\mathrm{A}+\mathrm{C})]$ in terms of the above matrix). Other things constant, the lower is the number in this columns the better is the indicator.

The various indicators differ significantly with respect to their adjusted noise-to-signal ratios. While this ratio is only 0.19 for the real exchange rate, it is 1.69 for the ratio of lending to deposit interest rates. The adjusted noise-to-signal ratio can be used as a criterium for deciding which indicators to drop from the list of possible indicators. A signaling device that issues signals at random times (and thus has no intrinsic predictive power) would obtain (with a sufficiently large sample) an adjusted noise-to-signal ratio equal to unity. Therefore, those indicators with an adjusted noise-to-signal ratio equal or higher than unity introduce excessive noise, and thus are not helpful in predicting crises. Thus, on the basis of the results presented in Table 5, there are four indicators that should be removed from the list of those to be used within the signals approach. These indicators are: the ratio of lending interest rates to deposit interest rates, bank deposits, imports, and the real interest rate differential. 
Another way of interpreting the above results regarding the noisiness of the indicators is by comparing the probability of a crisis conditional on a signal from the indicator, $A /(A+B)$ in terms of the above matrix, with the unconditional probability of a crisis- $(A+C) /(A+B+C+D)$ in terms of the above matrix. To the extent that the indicator has useful information, the conditional probability would be higher than the unconditional one. The sixth column of Table 5 presents the estimates of the conditional probabilities, while the eight column shows the difference between the conditional and unconditional probabilities for each of the indicators. From these estimates, it is clear that the set of indicators for which the conditional probability of a crisis is lower than the unconditional probability, is the same as the set for which the adjusted noise-to-signal ratio is higher than unity. In fact, it can be proven that the two conditions are equivalent.

\section{How leading are the leading indicators?}

The previous discussion has ranked the indicators according to their ability to predict crises while producing few false alarms. However, such criteria are silent as to the lead time of the signal. From the vantage point of a policymaker who wants to implement pre-emptive measures he/she will not be indifferent between an indicator that sends signals well before the crisis occurs and one that signals only when the crisis is imminent. In focussing on the 24-month window prior to the onset of the crisis, the criteria for ranking the indicators presented in Table 5 does not distinguish between a signal given 12 months prior to the crisis. and one given one month prior to the crisis.

To examine this issue, we tabulated for each of the indicators considered the average number of months in advance of the crisis when the first signal occurs; this, of course, does not preclude the fact that the indicator may continue to give signals through the entire period immediately preceding the crisis. Table 6 presents the results. Indeed, the most striking observation about these results is that, on average, all the indicators send the first signal anywhere between a year and a year-and-a-half before the crisis erupts, with the real exchange rate (our top-ranked indicator) offering the longest lead time. Hence, on this basis, all the indicators considered are leading rather than coincident, which is consistent with the spirit of an "early warning system."

\section{Persistence of the signals}

Another desirable feature in a potential leading indicator is that signals be more persistent prior to crises (i.e. during the 24-month window) than at other times. To assess the behavior of the indicators in this regard, the Table 7 presents a summary measure of the persistence of the signals (measured as the average number of signals per period) during the pre-crisis period relative to tranquil times. ${ }^{27}$ As in the previous tables, the indicators are ranked according to their performance. For instance, for the real exchange rate signals are more than five times more persistent prior to crises than in tranquil times. For most of the top-tier indicators, signals tend to be at least twice as persistent in pre-crisis periods relative to tranquil times.

\footnotetext{
${ }^{27} \mathrm{Clearly}$, this concept of persistence is just another way of looking at the noisiness of the indicators; the measure in Table 7 is just the inverse of the adjusted noise-to-signal ratio.
} 
The main conclusion that follows from the discussion above is that the signals approach can be useful as the basis for an early warning system of currency crises. Within this approach, a number of indicators have shown to be helpful in anticipating crises.

Furthermore, the results from the signals approach are consistent with previous work on this subject, as many of the indicators that proved to be useful within this approach (including the real exchange rate, domestic credit, money, international reserves, exports, and output) also received support from the review of the empirical literature presented in Section III. From the vantage point of an early warning system, the results are encouraging in that the signaling, on average, occurs sufficiently early to allow for pre-emptive policy actions.

\section{Concluding Remarks}

The studies reviewed in this paper indicate that an effective warning system for currency crises should take into account a broad variety of indicators, as these crises are usually preceded by symptoms that arise in a number of areas. Indicators that have proven to be particularly useful in anticipating crises include the behavior of international reserves, the real exchange rate, domestic credit, credit to the public sector, and domestic inflation. Other indicators that have found support include the trade balance, export performance, money growth, real GDP growth, and the fiscal deficit. The conclusions regarding the remaining indicators examined in this paper are necessarily tentative, in part because of the limited number of studies that formally tested their statistical significance in a variety of circumstances.

This paper has proposed a specific early warning system for currency crises. This system basically involves monitoring the behavior of a number of indicators, and recording the "signals" issued by these indicators as they move beyond certain threshold levels. On any given month, the system would estimate the probability of a crisis within the following 24 months conditional on the indicators issuing signals at that moment. Since the group of indicators that are issuing signals would be identified, this would provide information about the source and breath of the problems that underlie the probability of a crisis. The evidence presented in this paper, based on the performance of individual indicators, has provided some support for the signals approach.

Future work on the signals approach could combine the information on the various indicators to estimate the probability of a crisis conditional on simultaneous signals from any subset of indicators. Constructing and evaluating the performance of composite indices also appear as a natural extension of this analysis.

Finally, it is important to recognize that while an early warning system would be an useful tool for a timely assessment of the likelihood of a currency crisis, any such system is also subject to limitations. There could be a number of issues, including of a political and institutional nature, that may be relevant for a particular country at a particular moment in time, and which are not incorporated in the warning system. A comprehensive assessment of the situation would necessarily need to take those issues into account. Only then it would be possible to have a coherent interpretation of events and a firm base for policy decisions. 
Table 1. Indicators of Crises: A Review of the Literature

\begin{tabular}{|c|c|c|c|c|}
\hline Study & $\begin{array}{l}\text { Sample and } \\
\text { Frequency }\end{array}$ & $\begin{array}{l}\text { Country } \\
\text { Coverage }\end{array}$ & Indicators & Comments \\
\hline $\begin{array}{l}\text { Bilson } \\
\text { (1979) }\end{array}$ & $\begin{array}{l}1955-1977, \\
\text { annual }\end{array}$ & $\begin{array}{l}32 \text { countries with } \\
\text { emphasis on Ecuador, } \\
\text { Mexico, and Peru. } \\
\text { Devaluations of at least } \\
5 \text { percent. }\end{array}$ & $\begin{array}{l}\text { (1) international reserves/base money } \\
\text { (2) "shadow" exchange rate }\end{array}$ & $\begin{array}{l}\text { Use (2) to assess the size of the } \\
\text { devaluation and (1) as an } \\
\text { indicator of the probability of a } \\
\text { devaluation }\end{array}$ \\
\hline $\begin{array}{l}\text { Blanco and } \\
\text { Garber (1986) }\end{array}$ & $\begin{array}{l}1973-1981 \\
\text { quarterly }\end{array}$ & Mexico & (1) domestic credit growth & $\begin{array}{l}\text { Focuses on the one-step ahead } \\
\text { probability of devaluation, the } \\
\text { expected exchange rate } \\
\text { conditional on a devaluation, and } \\
\text { the unconditional expected } \\
\text { exchange rate. }\end{array}$ \\
\hline $\begin{array}{l}\text { Calvo and } \\
\text { Mendoza } \\
\text { (1995) }\end{array}$ & $\begin{array}{l}1983-1994, \\
\text { monthly and } \\
\text { quarterly }\end{array}$ & Mexico & $\begin{array}{l}\text { (1) M2 (in dollars)/reserve } \\
\text { (2) the money demand-supply gap }\end{array}$ & $\begin{array}{l}\text { Stress on growing stock } \\
\text { imbalances and maturity } \\
\text { mismatches in the financial sector } \\
\text { in explaining the crisis. }\end{array}$ \\
\hline Collins (1995) & $\begin{array}{l}1979-1991 \\
\text { annual }\end{array}$ & $\begin{array}{l}18 \text { countries with } \\
\text { pegged exchange rates } \\
\text { at the beginning of } \\
1979\end{array}$ & $\begin{array}{l}\text { (1) international reserves/GDP } \\
\text { (2) real GDP growth } \\
\text { (3) change in the real exchange rate } \\
\text { (4) multiple exchange rate dummy } \\
\text { (5) inflation } \\
\text { (6) current account/GDP } \\
\text { (7) foreign aid }\end{array}$ & $\begin{array}{l}\text { (1)-(4) are used to determine the } \\
\text { distance from the critical } \\
\text { threshold at which a country } \\
\text { devalues and (5)-(7) are used to } \\
\text { determine the mean rate at which } \\
\text { the economy is moving toward } \\
\text { the critical level. The implied } \\
\text { probabilities of exchange rate } \\
\text { adjustment withing } 6 \text { to } 60 \\
\text { months are calculated. }\end{array}$ \\
\hline $\begin{array}{l}\text { Cumby and } \\
\text { Van } \\
\text { Wijenbergen } \\
\text { (1989) }\end{array}$ & $\begin{array}{l}\text { 1979-1980, } \\
\text { monthly }\end{array}$ & Argentina & (1) domestic credit growth & $\begin{array}{l}\text { Focuses on the one-step ahead } \\
\text { probability of collapse. }\end{array}$ \\
\hline $\begin{array}{l}\text { Dornbusch, } \\
\text { Goldfajn, and } \\
\text { Valdes (1995) }\end{array}$ & $\begin{array}{l}1975-1995 \\
\text { annual } \\
\text { quarterly }\end{array}$ & $\begin{array}{l}\text { Argentina, Brazil, } \\
\text { Chile, Finland, and } \\
\text { Mexico. Other } \\
\text { currency crashes are } \\
\text { also discussed. }\end{array}$ & $\begin{array}{l}\text { (1) real exchange rate } \\
\text { (2) real interest rates } \\
\text { (3) GDP growth } \\
\text { (4) inflation } \\
\text { (5) fiscal deficit/GDP } \\
\text { (6) credit growth } \\
\text { (7) trade balance/GDP } \\
\text { (8) current account/GDP } \\
\text { (9) international reserves } \\
\text { (10) debt/GDP }\end{array}$ & $\begin{array}{l}\text { While no formal tests are } \\
\text { performed, the discussion focuses } \\
\text { on the common patterns in the } \\
\text { periods leading up to currency } \\
\text { crises. }\end{array}$ \\
\hline
\end{tabular}

Note: Additional details on the individual countries included in the larger cross-country studies are available in the original studies. 
Table 1. Indicators of Crises: A Review of the Literature

\begin{tabular}{|c|c|c|c|c|}
\hline Study & $\begin{array}{l}\text { Sample and } \\
\text { Frequency }\end{array}$ & $\begin{array}{l}\text { Country } \\
\text { Coverage }\end{array}$ & Indicators & Comments \\
\hline $\begin{array}{l}\text { Edin and } \\
\text { Vredin (1993) }\end{array}$ & $\begin{array}{l}1978-1989 \\
\text { monthly }\end{array}$ & $\begin{array}{l}\text { Denmark, Finland, } \\
\text { Sweden and Norway. } \\
16 \text { devaluations, } \\
\text { defined as shifts in the } \\
\text { entire target zone. }\end{array}$ & $\begin{array}{l}\text { (1) money } \\
\text { (2) output } \\
\text { (3) foreign interest rate } \\
\text { (4) foreign price level } \\
\text { (5) real exchange rate } \\
\text { (6) international reserves/imports } \\
\text { (7) trade balance }\end{array}$ & $\begin{array}{l}\text { Estimate the one-step ahead } \\
\text { probability of devaluation, and } \\
\text { the expected size of the } \\
\text { devaluation (measured as the } \\
\text { change in the central parity of the } \\
\text { target zone) conditional on a } \\
\text { devaluation taking place. }\end{array}$ \\
\hline $\begin{array}{l}\text { Edwards } \\
\text { (1989) }\end{array}$ & $\begin{array}{l}1962-82, \\
\text { pooled } \\
\text { quarterly data } \\
\text { and annual }\end{array}$ & $\begin{array}{l}39 \text { devaluations; } \\
24 \text { developing } \\
\text { countries with a fixed } \\
\text { exchange rate for at } \\
\text { least } 10 \text { years serve as } \\
\text { the control group. The } \\
\text { devaluations were at } \\
\text { least } 15 \text { percent with } \\
\text { respect to the } \\
\text { U.S. dollar after having } \\
\text { fixed the rate at least } \\
\text { two years. }\end{array}$ & $\begin{array}{l}\text { (1) central bank foreign assets/base } \\
\text { money } \\
\text { (2) net foreign assets/M1 } \\
\text { (3) domestic credit to public } \\
\text { sector/total credit } \\
\text { (4) bilateral real exchange rate } \\
\text { (5) parallel market premium } \\
\text { (6) growth of credit } \\
\text { (7) growth of credit to the public } \\
\text { sector } \\
\text { (8) public sector credit growth/GDP } \\
\text { (9) fiscal deficit/GDP } \\
\text { (10) current account/GDP } \\
\text { (11) the terms of trade } \\
\text { (12) errors and omissions plus short- } \\
\text { term capital } \\
\text { (13) exchange controls }\end{array}$ & $\begin{array}{l}\text { The focus is on understanding the } \\
\text { causes of devaluations. (1)-(5) } \\
\text { are used to estimate the } \\
\text { probability of devaluation and } \\
\text { (6)-(12) are used to describe the } \\
\text { stylized facts of the } 3 \text { years } \\
\text { preceding the devaluation. }\end{array}$ \\
\hline $\begin{array}{l}\text { Edwards and } \\
\text { Montiel (1989) }\end{array}$ & $\begin{array}{l}1962-1982, \\
\text { annual }\end{array}$ & $\begin{array}{l}20 \text { devaluations of at } \\
\text { least } 15 \text { percent with } \\
\text { respect to the } \\
\text { U.S. dollar after having } \\
\text { a fixed rate at least two } \\
\text { years. }\end{array}$ & $\begin{array}{l}\text { Same as (3)-(11) in Edwards (1989), } \\
\text { and manufacturing real wages. }\end{array}$ & $\begin{array}{l}\text { The stylized facts of } 3,1 \text {, and } 0 \\
\text { years before the devaluation are } \\
\text { described. }\end{array}$ \\
\hline $\begin{array}{l}\text { Edwards and } \\
\text { Santaella } \\
\text { (1993) }\end{array}$ & $\begin{array}{l}\text { 1954-1971, } \\
\text { annual }\end{array}$ & $\begin{array}{l}48 \text { devaluations ( } 26 \\
\text { under an IMF program) }\end{array}$ & $\begin{array}{l}\text { Same as (2)-(10) in Edwards (1989). } \\
\text { (14) number of official exchange rates } \\
\text { (15) political unpopularity } \\
\text { (16) democracy } \\
\text { (17) political violence } \\
\text { (18) Ideology (how leftist) } \\
\text { (19) number of coups } \\
\text { (20) relative GDP per capita }\end{array}$ & $\begin{array}{l}\text { The evolution of }(2)-(10) \text { and } \\
\text { (14) is compared for devaluers } \\
\text { and nondevaluers. Some of these } \\
\text { variables and (15)-( } 20) \text { are used } \\
\text { to estimate the probability of } \\
\text { entering into an IMF program. }\end{array}$ \\
\hline
\end{tabular}

Note: Additional details on the individual countries included in the larger cross-country studies are available in the original studies. 
Table 1. Indicators of Crises: A Review of the Literature

\begin{tabular}{|c|c|c|c|c|}
\hline Study & $\begin{array}{l}\text { Sample and } \\
\text { Frequency }\end{array}$ & $\begin{array}{l}\text { Country } \\
\text { Coverage }\end{array}$ & Indicators & Comments \\
\hline $\begin{array}{l}\text { Eichengreen, } \\
\text { Rose and } \\
\text { Wyplosz } \\
\text { (1995) }\end{array}$ & $\begin{array}{l}\text { 1959-1993, } \\
\text { quarterly }\end{array}$ & $\begin{array}{l}20 \text { industrial countries; } \\
78 \text { crises, } 33 \text { successful } \\
\text { attacks and } \\
45 \text { successful defenses. }\end{array}$ & $\begin{array}{l}\text { The authors mention that many of } \\
\text { (1)-(16) are defined with respect to } \\
\text { the same variable in Germany, but do } \\
\text { not specify which of them. } \\
\text { (1) change in international reserves } \\
\text { (2) real effective exchange rate } \\
\text { (3) credit growth } \\
\text { (4) M1 growth } \\
\text { (5) bond yield } \\
\text { (6) interest rates } \\
\text { (7) stock prices } \\
\text { (8) inflation } \\
\text { (9) wage growth } \\
\text { (10) GDP growth } \\
\text { (11) unemployment rate } \\
\text { (12) employment growth } \\
\text { (13) fiscal deficit/GDP } \\
\text { (14) current account/GDP } \\
\text { (15) change in exports } \\
\text { (16) change in imports } \\
\text { (17) government victory } \\
\text { (18) government loss } \\
\text { (19) elections } \\
\text { (20) change in government } \\
\text { (21) capital controls } \\
\text { (22) left-wing government } \\
\text { (23) new finance minister } \\
\text { (24) past exchange market crisis } \\
\text { (25) past exchange market event }\end{array}$ & $\begin{array}{l}\text { The behavior of (1)-(16) is } \\
\text { examined during the four years } \\
\text { around crises and events } \\
\text { compared to the evolution of } \\
\text { these variables around periods of } \\
\text { tranquility. "Events" include } \\
\text { significant changes in exchange } \\
\text { arrangements (such as } \\
\text { devaluations, decisions to float, } \\
\text { and widening of exchange rate } \\
\text { bands); "crises" overlap with } \\
\text { events but includes unsuccessful } \\
\text { speculative attacks and excludes } \\
\text { changes in exchange } \\
\text { arrangements not associated with } \\
\text { market pressures. The association } \\
\text { between (17)-(23) and foreign } \\
\text { exchange market events is also } \\
\text { examined. A subset of (1)-( } 25) \text { is } \\
\text { then used to estimate the } \\
\text { probability of: a successful } \\
\text { defense, devaluation, revaluation, } \\
\text { floating, fixing, and other events. }\end{array}$ \\
\hline $\begin{array}{l}\text { Flood and } \\
\text { Marion (1995) }\end{array}$ & $\begin{array}{l}1957-1991 \\
\text { monthly }\end{array}$ & $\begin{array}{l}17 \text { Latin American } \\
\text { countries; } 80 \text { peg } \\
\text { periods of a duration of } \\
\text { at least } 3 \text { months. }\end{array}$ & $\begin{array}{l}\text { (1) drift of the real exchange rate } \\
\text { (2) variance of the real exchange rate }\end{array}$ & $\begin{array}{l}\text { A model is developed and tested } \\
\text { that examines the size and the } \\
\text { timing of devaluations-that is } \\
\text { the duration of the peg; the focus } \\
\text { is on trade-off between the cost } \\
\text { of realigning and the costs of a } \\
\text { misalignment. }\end{array}$ \\
\hline
\end{tabular}

Note: Additional details on the individual countries included in the larger cross-country studies are available in the original studies. 
Table 1. Indicators of Crises: A Review of the Literature

\begin{tabular}{|c|c|c|c|c|}
\hline Study & $\begin{array}{l}\text { Sample and } \\
\text { Frequency }\end{array}$ & $\begin{array}{l}\text { Country } \\
\text { Coverage }\end{array}$ & Indicators & Comments \\
\hline $\begin{array}{l}\text { Frankel and } \\
\text { Rose (1996) }\end{array}$ & $\begin{array}{l}1971-1992, \\
\text { annual }\end{array}$ & $\begin{array}{l}105 \text { developing } \\
\text { countries; } \\
117 \text { devaluations of at } \\
\text { least } 25 \text { percent; for } \\
\text { high-inflation countries } \\
\text { these musts exceed the } \\
\text { previous year by at } \\
\text { least } 10 \text { percent. }\end{array}$ & $\begin{array}{l}\text { (1) credit growth } \\
\text { (2) fiscal deficit/GDP } \\
\text { (3) per-capita GDP growth } \\
\text { (4) external debt/GDP } \\
\text { (5) reserves/imports } \\
\text { (6) current account/GDP } \\
\text { (7) deviations from PPP in the } \\
\text { bilateral real exchange rate } \\
\text { (8) OECD GDP growth } \\
\text { (9) foreign interest rate } \\
\text { The following variables as a share of } \\
\text { total debt: } \\
\text { (10) commercial bank loans } \\
\text { (11) concessional loans } \\
\text { (12) variable rate debt } \\
\text { (13) short-term debt } \\
\text { (14) public sector debt } \\
\text { (15) multilateral development bank } \\
\text { loans } \\
\text { (16) flow of FDI }\end{array}$ & $\begin{array}{l}\text { (1)-(16) are examined to provide } \\
\text { a broad characterization of } \\
\text { currency crashes. The evolution } \\
\text { of these indicators around crises } \\
\text { is compared to the behavior } \\
\text { during tranquil periods. The } \\
\text { indicators are used to predict the } \\
\text { probability of a crash. }\end{array}$ \\
\hline $\begin{array}{l}\text { Goldstein } \\
\text { (1996) }\end{array}$ & $\begin{array}{l}\text { annual and } \\
\text { monthly }\end{array}$ & $\begin{array}{l}\text { Argentina, Brazil, } \\
\text { Chile, and Mexico. } \\
\text { Other crises are also } \\
\text { discussed. }\end{array}$ & $\begin{array}{l}\text { (1) international interest rates } \\
\text { (2) mismatch between the government } \\
\text { and banking sectors short-term assets } \\
\text { and liabilities (such as M3/reserves) } \\
\text { (3) current account/GDP particularly } \\
\text { one driven by a fall in saving } \\
\text { (4) boom in bank lending followed by } \\
\text { a decline in asset prices } \\
\text { (5) real exchange rate } \\
\text { (6) short-term borrowing } \\
\text { (7) weak banking sector }\end{array}$ & $\begin{array}{l}\text { There are no formal tests, but (1)- } \\
\text { ( } 7) \text { are used to discuss why some } \\
\text { countries were more vulnerable } \\
\text { than others in the wake of the } \\
\text { Mexican crisis and the factors } \\
\text { behind the crisis in Mexico. }\end{array}$ \\
\hline $\begin{array}{l}\text { Humberto, } \\
\text { Julio, and } \\
\text { Herrera } \\
\text { (1991) }\end{array}$ & monthly & Colombia & $\begin{array}{l}\text { (1) credit growth } \\
\text { (2) parallel market premium }\end{array}$ & $\begin{array}{l}\text { Calculate the one-step ahead } \\
\text { probability of devaluation. }\end{array}$ \\
\hline Kamin (1988) & $\begin{array}{l}\text { 1953-1983, } \\
\text { annual }\end{array}$ & $\begin{array}{l}107 \text { devaluations of at } \\
\text { least } 15 \text { percent with } \\
\text { respect to the } \\
\text { U.S. dollar. }\end{array}$ & $\begin{array}{l}\text { (1) trade balance/GDP } \\
\text { (2) import growth } \\
\text { (3) export growth } \\
\text { (4) capital flows/GDP } \\
\text { (5) changes in reserves } \\
\text { (6) inflation } \\
\text { (7) the real exchange rate } \\
\text { (8) real GDP growth } \\
\text { (9) change in export prices }\end{array}$ & $\begin{array}{l}\text { The evolution of (1)-(9) is } \\
\text { examined } 3 \text { years before and } \\
4 \text { years after the devaluations and } \\
\text { is compared with the evolution of } \\
\text { the same variables in the control } \\
\text { group. }\end{array}$ \\
\hline
\end{tabular}

Note: Additional details on the individual countries included in the larger cross-country studies are available in the original studies.

Table 1. Indicators of Crises: A Review of the Literature

\begin{tabular}{ccccc} 
Study & $\begin{array}{c}\text { Sample and } \\
\text { Frequency }\end{array}$ & $\begin{array}{c}\text { Country } \\
\text { Coverage }\end{array}$ & Indicators & Comments \\
\hline
\end{tabular}




\begin{tabular}{|c|c|c|}
\hline $\begin{array}{l}\text { Kaminsky and } \\
\text { Leiderman } \\
\text { (1995) }\end{array}$ & $\begin{array}{l}1985-1987 \text {, } \\
\text { monthly }\end{array}$ & $\begin{array}{l}\text { Argentina, Israel, and } \\
\text { Mexico }\end{array}$ \\
\hline $\begin{array}{l}\text { Kaminsky and } \\
\text { Reinhart } \\
\text { (1996) }\end{array}$ & $\begin{array}{l}\text { 1970-1995, } \\
\text { monthly }\end{array}$ & $\begin{array}{l}20 \text { countries; } \\
5 \text { industrial and } \\
15 \text { developing; } \\
76 \text { currency crises and } \\
26 \text { banking crises }\end{array}$ \\
\hline
\end{tabular}

Klein and Marion

(1994)

$\begin{array}{ll}\begin{array}{l}\text { Krugman } \\ \text { (1996) }\end{array} & \begin{array}{l}1988-1995, \\ \text { annual, } \\ \text { quarterly, some } \\ \text { daily }\end{array}\end{array}$

1957-1991, monthly

87 peg episodes, as in Flood and Marion (1995).

France, Italy, Spain, Sweden, and the United Kingdom during the 1992-93

\section{(1) monetary shocks \\ (2) fiscal shocks \\ (3) past inflation}

(1) export growth

(2) import growth

(3) bilateral real exchange rate-deviation from trend

(4) terms of trade changes

(5) changes in reserves

(6) money demand/supply gap

(7) changes in bank deposits

(8) real interest rates

(9) lending-deposit spread

(10) domestic-foreign real interest rate differential

(11) M2 money multiplier

(12) $\mathrm{M} 2$ /international reserves

(13) growth in domestic credit/GDP

(14) changes in stock prices

(15) output growth

(16) financial liberalization

(17) banking crises

(1) bilateral real exchange rates

(2) real exchange rate squared

(3) net foreign assets of the monetary sector/M1

(4) net foreign assets of the monetary sector/M1 squared

(5) openness

(6) trade concentration

(7) regular executive transfers

(8) irregular executive transfers

(9) months spent in the peg ERM crises.
(1) unemployment rate

(3) inflation

(4) public debt/GDP
(2) output gap
Discuss the probability of crisis in exchange-rate-based stabilization programs.

The behavior of (1)-(15) is examined 18 months before and after the crises and compared to the behavior of these indicators during "tranquil" periods. (16-17) are used in predicting the probability of crises. The usefulness of all the indicators is assessed by: (a) determining whether they gave a signal on a crisis by crisis basis; (b) tabulating the probability of crisis conditioned on a signal from the individual indicator; and (c) tabulating the probability of false signals.

Using pooled data (1)-(8) are used to estimate the probability of devaluation at $t+1$; the sample is disaggregated into pre- and post-Bretton Woods period and distinctions are made between pegs that are followed by either a float or a crawling peg from devaluations followed by a new peg.

While the bulk of the paper is theoretical, evidence on the trends of (1)-(4) is used to support the argument that the ERM episode does not provide evidence of self-fulfilling crises.

Note: Additional details on the individual countries included in the larger cross-country studies are available in the original studies. 
Table 1. Indicators of Crises: A Review of the Literature

\begin{tabular}{|c|c|c|c|c|}
\hline Study & $\begin{array}{l}\text { Sample and } \\
\text { Frequency }\end{array}$ & $\begin{array}{l}\text { Country } \\
\text { Coverage }\end{array}$ & Indicators & Comments \\
\hline $\begin{array}{l}\text { Milesi-Ferretti } \\
\text { and Razin } \\
\text { (1995) }\end{array}$ & $\begin{array}{l}\text { 1970-94, } \\
\text { annual }\end{array}$ & $\begin{array}{l}\text { Chile and Mexico have } \\
\text { the } 4 \text { crises cases; } \\
\text { Ireland, Israel, and } \\
\text { South Korea are no } \\
\text { crises cases due to } \\
\text { policy reversal; and } \\
\text { Australia no crisis case } \\
\text { with no policy change. }\end{array}$ & $\begin{array}{l}\text { (1) debt service/GDP adjusted for } \\
\text { GDP growth and changes in the real } \\
\text { exchange rate } \\
\text { (2) exports/GDP } \\
\text { (3) real exchange rate versus } \\
\text { historical norm } \\
\text { (4) saving/GDP } \\
\text { (5) fiscal stance } \\
\text { (6) fragility of the banking sector } \\
\text { (7) political instability } \\
\text { (8) composition of capital flows }\end{array}$ & $\begin{array}{l}\text { The emphasis is on developing a } \\
\text { notion of current account } \\
\text { sustainability and the factors it } \\
\text { depends on. While there is no } \\
\text { formal test, (1)-( } 8 \text { ) are used to } \\
\text { compare the crises and no crises } \\
\text { episodes. }\end{array}$ \\
\hline Moreno (1995) & $\begin{array}{l}\text { 1980-94, } \\
\text { monthly and } \\
\text { quarterly }\end{array}$ & $\begin{array}{l}\text { Indonesia, Japan, } \\
\text { Malaysia, Philippines, } \\
\text { Singapore, Korea, and } \\
\text { Thailand. } 126 \text { episodes } \\
\text { of speculative } \\
\text { pressures; } 72 \text { in the } \\
\text { direction of } \\
\text { depreciation and } 54 \text { in } \\
\text { the direction of } \\
\text { appreciation. }\end{array}$ & $\begin{array}{l}\text { (1) change in bilateral exchange rate } \\
\text { (2) changes in net foreign assets } \\
\text { (central bank) } \\
\text { (3) domestic-foreign interest rate } \\
\text { differential } \\
\text { (4) exports/imports } \\
\text { (5) output gap } \\
\text { All the following are relative to the } \\
\text { United States: } \\
\text { (6) growth of domestic credit/reserve } \\
\text { money } \\
\text { (7) growth in M1 } \\
\text { (8) growth in broad money } \\
\text { (9) fiscal deficit/government spending } \\
\text { (10) inflation }\end{array}$ & $\begin{array}{l}\text { The emphasis is on testing } \\
\text { whether the behavior of } \\
\text { macroeconomic variables (4)- } \\
\text { (10) differs between "tranquil" } \\
\text { and "speculative" periods. (1)-(3) } \\
\text { are used to define such periods. }\end{array}$ \\
\hline $\begin{array}{l}\text { Otker and } \\
\text { Pazarbasioglu } \\
\text { (1994) }\end{array}$ & $\begin{array}{l}\text { 1979-93, } \\
\text { monthly }\end{array}$ & $\begin{array}{l}\text { Denmark, Ireland, } \\
\text { Norway, Spain, and } \\
\text { Sweden. The sample } \\
\text { covers } 15 \text { devaluations } \\
\text { and } 10 \text { realignments of } \\
\text { all central rats. }\end{array}$ & $\begin{array}{l}\text { (1) domestic credit } \\
\text { (2) real effective exchange rate } \\
\text { (3) trade balance } \\
\text { (4) unemployment rate } \\
\text { (5) German price level } \\
\text { (6) output } \\
\text { (7) reserves } \\
\text { (8) central parity } \\
\text { (9) foreign-domestic interest rate } \\
\text { differential } \\
\text { (10) position within band }\end{array}$ & $\begin{array}{l}\text { The aim is to use (1)-(10) to } \\
\text { estimate the probability of } \\
\text { abandoning the peg by either } \\
\text { devaluing or floating. (1)-( }(8) \text { are } \\
\text { associated for macroeconomic } \\
\text { "fundamentals" while (7), (9), } \\
\text { and (10) are proxies for } \\
\text { "speculative factors." }\end{array}$ \\
\hline
\end{tabular}

Note: Additional details on the individual countries included in the larger cross-country studies are available in the original studies. 
Table 1. Indicators of Crises: A Review of the Literature (concluded)

\begin{tabular}{|c|c|c|c|c|}
\hline Study & $\begin{array}{l}\text { Sample and } \\
\text { Frequency }\end{array}$ & $\begin{array}{l}\text { Country } \\
\text { Coverage }\end{array}$ & Indicators & Comments \\
\hline $\begin{array}{l}\text { Otker and } \\
\text { Pazarbasioglu } \\
\text { (1995) }\end{array}$ & $\begin{array}{l}\text { 1982-1994, } \\
\text { monthly }\end{array}$ & $\begin{array}{l}\text { Mexico. During the } \\
\text { sample there are } \\
4 \text { devaluations; } \\
3 \text { increases in the rate } \\
\text { of crawl, and } 2 \\
\text { reductions; and } 2 \text { shifts } \\
\text { to a more flexible } \\
\text { exchange system. }\end{array}$ & $\begin{array}{l}\text { (1) real exchange rate } \\
\text { (2) international reserves } \\
\text { (3) inflation differential with the } \\
\text { United States } \\
\text { (4) output growth } \\
\text { (5) U.S. interest rates } \\
\text { (6) central bank credit to the banking } \\
\text { system } \\
\text { (7) financial sector reform dummy } \\
\text { (8) share of short-term foreign } \\
\text { currency debt } \\
\text { (9) fiscal deficit } \\
\text { (10) current account balance }\end{array}$ & $\begin{array}{l}\text { (1)-(10) are used to estimate the } \\
\text { one-step ahead probability of a } \\
\text { regime change. The relative } \\
\text { importance of the indicators is } \\
\text { assessed for pre- and post- } \\
\text { November } 1991 \text {, when the dual } \\
\text { exchange rate system was } \\
\text { abandoned. }\end{array}$ \\
\hline $\begin{array}{l}\text { Sachs, Tornell, } \\
\text { and Velasco } \\
\text { (1995) }\end{array}$ & $\begin{array}{l}1985-1995, \\
\text { monthly and } \\
\text { annual }\end{array}$ & $\begin{array}{l}20 \text { emerging market } \\
\text { countries }\end{array}$ & $\begin{array}{l}\text { (1) the real exchange rate } \\
\text { (2) credit to the private sector/GDP } \\
\text { (3) M2/international reserves } \\
\text { (4) saving/GDP } \\
\text { (5) investment/GDP } \\
\text { (6) capital inflows/GDP } \\
\text { (7) short-term capital inflows/GDP } \\
\text { (8) government consumption/GDP } \\
\text { (9) current account/GDP }\end{array}$ & $\begin{array}{l}\text { The emphasis is on explaining } \\
\text { why some countries were more } \\
\text { affected by the Mexican crisis } \\
\text { than others. }\end{array}$ \\
\hline
\end{tabular}

Note: Additional details on the individual countries included in the larger cross-country studies are available in the original studies. 
Table 2. Indicators by Category

Sector

Indicators

\section{External \\ Capital account}

Debt profile

Current account

International
(1) international reserves/base money

(2) international reserves/GDP

(3) stock of international reserves

(4) reserves/imports

(5) growth in reserves

(6) central bank foreign assets/base money

(7) growth of central bank net foreign assets

(8) net foreign assets/M1

(9) net foreign assets/M1 squared

\section{(1) foreign aid}

(2) external debt/GDP

(3) public debt/GDP

(4) share of commercial bank loans

(5) share of concessional loans

(6) share of variable-rate debt

(1) change in real exchange rate

(2) level of the real exchange rate

(3) drift of the real exchange rate

(4) variance of the real exchange rate (5) deviations from PPP in the real bilateral exchange rate

(6) deviations from trend in the real exchange rate

(7) deviations from historical average of the real exchange rate

(8) real exchange rate squared

(1) OECD real GDP growth

(2) international interest rates
(10) errors and omissions plus short-term capital

(11) share capital flows in the form of short-term borrowing

(12) short-term capital flows/GDP

(13) FDI/debt

(14) capital account balance/GDP

(15) domestic-foreign real interest rate differential

(16) domestic-foreign nominal interest rate differential

(7) share of short-term debt

(8) share of public sector debt

(9) share of multilateral development bank loans

(10) debt service/GDP adjusted for GDP growth

(9) trade balance/GDP

(10) current account/GDP

(11) exports/GDP

(12) exports/imports

(13) change in exports

(14) change in imports

(15) saving/GDP

(16) investment/GDP

(17) change in the terms-of-trade

(18) change in export prices

(3) U.S. interest rates

(4) foreign price level 
Table 2. Indicators by Category (concluded)

Sector

\section{Financial}

Financial liberalization

Other financial

Real sector

Fiscal

Institutional/structural

Political
(1) real interest rates

(2) credit growth

(3) growth in credit/GDP

(4) lending-deposit interest rate spread

(1) "shadow" exchange rate

(2) parallel market premium

(3) central parity

(4) position within the band

(5) central bank credit to the banking system

(6) money demand-supply gap

(7) M1 growth

(8) M1 level

(1) real GDP growth

(2) per-capita growth

(3) output level

(4) output gap

(5) manufacturing real wages

(1) fiscal deficit/GDP

(2) fiscal deficit/government spending relative to the United States

(3) government consumption/GDP

(1) multiple exchange rate dummy

(2) exchange controls dummy

(3) relative GDP per capita

(4) financial liberalization dummy

(5) banking crisis dummy

(1) government victory dummy

(2) government loss dummy

(3) elections

(4) change in government

(5) legal executive transfers
Indicators

(5) growth in M2 multiplier

(6) growth of credit/reserve money

relative to the United States

(9) M1 growth relative to the United States

(10) broad money growth relative to the United States

(11) change in bank deposits

(12) bond-yields

(13) inflation

(14) inflation relative to the US

(15) M2/international reserves

(6) wage growth

(7) unemployment rate

(8) employment growth

(9) changes in stock prices

(4) domestic credit to public sector/total credit

(5) growth in public sector credit

(6) public sector credit growth/GDP

(6) openness

(7) trade concentration

(8) months spent on peg

(9) past foreign exchange market crisis

(10) past foreign exchange market event

(6) illegal executive transfers

(7) degree of political instability

(8) left-wing government

(9) new finance minister 
Table 3. Indicators of Crises: What Worked Best?

\begin{tabular}{|c|c|c|c|}
\hline Study & "Preferred" Indicators & Comments & Other Issues \\
\hline Bilson (1979) & $\begin{array}{l}\text { (1) international reserves/base } \\
\text { money }\end{array}$ & $\begin{array}{l}\text { The probability of a } \\
\text { devaluation one year } \\
\text { increases from about } \\
5 \text { percent for countries in } \\
\text { which ( } 1 \text { ) is } 30 \text { percent or } \\
\text { greater, to } 40 \text { percent for } \\
\text { countries where (1) is less } \\
\text { than } 10 \text { percent. }\end{array}$ & $\begin{array}{l}\text { The shadow exchange rate } \\
\text { appears to have some } \\
\text { predictive power, but no } \\
\text { formal tests are conducted. }\end{array}$ \\
\hline Collins (1995) & $\begin{array}{l}\text { (1) international } \\
\text { reserves/GDP } \\
\text { (2) real GDP growth } \\
\text { (3) inflation }\end{array}$ & $\begin{array}{l}\text { (1) is the key determinant of } \\
\text { the distance from threshold; } \\
\text { (2) is marginally significant; } \\
\text { (3) is the key determinant of } \\
\text { the mean rate at which the } \\
\text { economy is moving toward } \\
\text { the critical level. }\end{array}$ & $\begin{array}{l}\text { The remaining } 4 \text { variables } \\
\text { were statistically } \\
\text { insignificant. The model } \\
\text { worked best in predicting } \\
\text { exchange rate adjustments } \\
\text { within } 12 \text { months; countries } \\
\text { which actually adjusted } \\
\text { showed an estimated } \\
\text { probability of } 46 \text { percent } \\
\text { versus a } 28 \text { percent } \\
\text { probability for those that did } \\
\text { not adjust. }\end{array}$ \\
\hline Edin and Vredin (1993) & $\begin{array}{l}\text { (1) money } \\
\text { (2) output } \\
\text { (3) international } \\
\text { reserves/imports }\end{array}$ & $\begin{array}{l}\text { (1)-(3) have a significant } \\
\text { effect on the probability of } \\
\text { devaluation. (1), ( } 2 \text { ), and the } \\
\text { real exchange rate have a } \\
\text { significant effect on the size } \\
\text { of the devaluation. }\end{array}$ & $\begin{array}{l}\text { The remaining variables were } \\
\text { statistically insignificant. The } \\
\text { estimates of the probability of } \\
\text { devaluation seems robust, but } \\
\text { those of the size of } \\
\text { devaluations are much less } \\
\text { robust. }\end{array}$ \\
\hline Edwards (1989) & $\begin{array}{l}\text { (1) central bank foreign } \\
\text { assets/base money } \\
\text { (2) net foreign assets/M1 } \\
\text { (3) domestic credit to public } \\
\text { sector/total credit } \\
\text { (4) bilateral real exchange } \\
\text { rate } \\
\text { (5) parallel market premium } \\
\text { (6) growth of credit } \\
\text { (7) growth of credit to the } \\
\text { public sector } \\
\text { (8) public sector credit } \\
\text { growth/GDP } \\
\text { (9) fiscal deficit/GDP } \\
\text { (10) current account/GDP }\end{array}$ & $\begin{array}{l}\text { (1)-(5) have the predicted } \\
\text { effects on the probability of a } \\
\text { devaluation and }(6)-(10) \text { are } \\
\text { significantly different for the } \\
\text { devaluers than for the control } \\
\text { group. }\end{array}$ & $\begin{array}{l}\text { The remaining variables were } \\
\text { not significantly different } \\
\text { across the two groups of } \\
\text { countries. Since the data is } \\
\text { annual and the variables are } \\
\text { lagged one period, these are } \\
\text { one-year ahead predictions. }\end{array}$ \\
\hline
\end{tabular}


Table 3. Indicators of Crises: What Worked Best?

\begin{tabular}{ll}
\hline \multicolumn{1}{c|}{ Study } & \multicolumn{1}{c}{ "Preferred" Indicators } \\
Eichengreen, Rose, and & (1) inflation \\
Wyplosz (1995) & $\begin{array}{l}\text { (2) employment growth } \\
\text { (3) current account/GDP } \\
\end{array}$ \\
& (4) capital controls \\
& (5) government loss \\
& (6) past foreign exchange \\
& market crisis
\end{tabular}

Flood and Marion (1995)

(1) drift of the real exchange rate

(2) variance of the real exchange rate

Frankel and Rose (1996)

Kamin (1988)
(1) concessional debt/total debt

(2) public sector debt/total debt

(3) foreign direct

investment/total debt

(4) overvaluation of the real exchange rate

(5) reserves/imports

(6) foreign interest rate

(7) credit growth

(1) trade balance/GDP

(2) export growth

(3) import growth

(4) real exchange rate

(5) real GDP growth

(6) inflation
The size of the devaluation and the duration of the peg are significantly determined by (1)-(2) with the signs predicted by theory.

(1)-(7) help predict crises one year in advance. All the variables have the expected signs. Increases in (2), (4), (6), and (7) increase the probability of a crash; increases in (1), (3), and (5) have the opposite effect.

The evolution of (1)-(6) is significantly different for the devaluers than for the control group during 3 to 1 year before devaluation.
Other Issues

The variables that were not significant in the estimation of the probability of an attack includes: credit growth, GDP growth, unemployment rate, fiscal deficit/GDP, government victory, and past foreign exchange market event.

The overall fit of the equations (1)-(2) do better predicting the size of the devaluation than the time spent in peg, where the share of the explained variation is 35 percent or less, depending on the specification.

The remaining indicators were not significant in the multivariate probit estimation of the one-step ahead probability of a crash. Only 5 of 69 crises were predicted by the model.

The paper also examines the evolution of the indicators in the post-devaluation period. 
Table 3. Indicators of Crises: What Worked Best?

\begin{tabular}{|c|c|c|c|}
\hline Study & "Preferred" Indicators & Comments & Other Issues \\
\hline $\begin{array}{l}\text { Kaminsky and Reinhart } \\
\text { (1996) }\end{array}$ & $\begin{array}{l}\text { (1) export growth } \\
\text { (2) bilateral real exchange } \\
\text { rate--deviation from trend } \\
\text { (3) terms of trade changes } \\
\text { (4) changes in reserves } \\
\text { (5) money demand/supply } \\
\text { gap } \\
\text { (6) real interest rates } \\
\text { (7) M2 money multiplier } \\
\text { (8) M2/international reserves } \\
\text { (9) growth in domestic } \\
\text { credit/GDP } \\
\text { (10) changes in stock prices } \\
\text { (11) output growth } \\
\text { (12) banking crises }\end{array}$ & $\begin{array}{l}\text { In } 3 / 4 \text { of the crises at least } \\
60 \text { percent of the indicators } \\
\text { were giving a signal. External } \\
\text { sector variables and those } \\
\text { linked to financial } \\
\text { liberalization provided the } \\
\text { most accurate signals during } \\
\text { the } 12 \text { months before the } \\
\text { crises. Banking crisis help } \\
\text { predict the probability of a } \\
\text { balance-of-payments. }\end{array}$ & $\begin{array}{l}\text { The indicators are compared } \\
\text { on the basis of the percent of } \\
\text { crises accurately called and } \\
\text { on the noise-to-signal ratio. } \\
\text { (1), (6), and (8) have the } \\
\text { highest share of accurately- } \\
\text { called crises while (2) has the } \\
\text { lowest noise-to-signal ratio. }\end{array}$ \\
\hline Klein and Marion (1994) & $\begin{array}{l}\text { (1) bilateral real exchange } \\
\text { rates } \\
\text { (2) real exchange rate squared } \\
\text { (3) net foreign assets of the } \\
\text { monetary sector/M1 } \\
\text { (4) net foreign assets of the } \\
\text { monetary sector/M1 squared } \\
\text { (5) openness } \\
\text { (6) irregular } \\
\text { (7) regular executive transfers } \\
\text { (8) months spent in the peg }\end{array}$ & $\begin{array}{l}\text { (1)-(8) affect the probability } \\
\text { that the peg will be } \\
\text { abandoned; the significance } \\
\text { of }(2),(4) \text {, and }(7) \text { is } \\
\text { particularly sensitive to the } \\
\text { specification used. }\end{array}$ & \\
\hline Moreno (1995) & $\begin{array}{l}\text { (1) growth in broad money } \\
\text { relative to the United States } \\
\text { (2) fiscal deficit } \\
\text { (3) output } \\
\text { (4) inflation }\end{array}$ & $\begin{array}{l}\text { The differences were } \\
\text { significant for periods where } \\
\text { speculative pressures were in } \\
\text { the direction of depreciation. } \\
\text { If Japan is excluded from the } \\
\text { sample (2) is not significantly } \\
\text { different from tranquil } \\
\text { periods. }\end{array}$ & $\begin{array}{l}\text { The analysis is } \\
\text { contemporaneous, or using } \\
\text { only one month before the } \\
\text { speculative attack; hence, the } \\
\text { analysis does not say much } \\
\text { about whether the indicators } \\
\text { behave differently in the } \\
\text { periods leading up to the } \\
\text { crisis. }\end{array}$ \\
\hline $\begin{array}{l}\text { Otker and Pazarbasioglu } \\
\text { (1994) }\end{array}$ & $\begin{array}{l}\text { (1) domestic credit } \\
\text { (2) real effective exchange } \\
\text { rate } \\
\text { (3) trade balance } \\
\text { (4) foreign-domestic interest } \\
\text { rate differential } \\
\text { (5) unemployment rate } \\
\text { (6) German price level } \\
\text { (7) output } \\
\text { (8) international reserves } \\
\text { (9) central parity } \\
\text { (10) position within the band }\end{array}$ & $\begin{array}{l}\text { The importance of the } \\
\text { variables varied across } \\
\text { countries in individual } \\
\text { country regressions. In a } \\
\text { regression including all } \\
\text { countries (except Denmark, } \\
\text { because it had no } \\
\text { devaluation), the significant } \\
\text { variables were (2), (4), (5), } \\
\text { (6), and (10). }\end{array}$ & $\begin{array}{l}\text { The estimated probability of } \\
\text { devaluation increase } \\
\text { markedly ahead of } \\
\text { devaluations. }\end{array}$ \\
\hline
\end{tabular}


Table 3. Indicators of Crises: What Worked Best? (concluded)

\begin{tabular}{|c|c|}
\hline Study & "Preferred" Indicators \\
\hline $\begin{array}{l}\text { Otker and Pazarbasioglu } \\
\text { (1995) }\end{array}$ & $\begin{array}{l}\text { (1) real exchange rate } \\
\text { (2) international reserves } \\
\text { (3) inflation differential with } \\
\text { the United States } \\
\text { (4) central bank credit to the } \\
\text { banking system } \\
\text { (5) fiscal deficit } \\
\text { (6) financial sector reform } \\
\text { interaction dummy }\end{array}$ \\
\hline
\end{tabular}

Sachs, Tornell ,and Velasco (1995)
(1) change in real exchange rate

(2) change in credit to the private sector/GDP

(3) M2/international reserves

(4) short-term capital

inflows/GDP

(5) government

consumption/GDP
(1)-(2) are used to define whether the "fundamentals" are weak or strong, and (3) is used to define whether reserves are low or high. The simultaneous combination of weak fundamentals and low reserves made countries vulnerable to contagion effects following the Mexican crisis. (4) and (5) also had an effect, but only in the presence of weak fundamentals and low reserves.
Other Issues

The role of (4) becomes more important while the role of $(5)$ becomes less so in forecasting the December 1994 crisis. The predictive capacity of the model forecasting crisis 6 months ahead deteriorates considerably.

The remaining indicators were statistically insignificant. The exercise was intended to assess the factors that made countries vulnerable following the Mexican crisis. However, it does not assess the indicator properties of the variables in predicting individual crises within the $1986-95$ sample analyzed. 
Table 4. Performance of Indicators

\begin{tabular}{|c|c|c|c|}
\hline Sector & Variables & $\begin{array}{l}\text { Number of Studies } \\
\text { Considered }\end{array}$ & $\begin{array}{c}\text { Statistically Significant } \\
\text { Results }\end{array}$ \\
\hline Capital account & $\begin{array}{l}\text { international reserves } \\
\text { short-term capital flows } \\
\text { foreign direct investment } \\
\text { capital account balance } \\
\text { domestic-foreign interest differential }\end{array}$ & $\begin{array}{l}11 \\
2 \\
1 \\
1 \\
2\end{array}$ & $\begin{array}{c}10 \\
1 \\
1 \\
-- \\
1\end{array}$ \\
\hline Debt profile & $\begin{array}{l}\text { foreign aid } \\
\text { external debt } \\
\text { public debt } \\
\text { share of commercial bank loans } \\
\text { share of concessional loans } \\
\text { share of variable-rate debt } \\
\text { share of short-term debt } \\
\text { share of multilateral development } \\
\text { bank debt }\end{array}$ & $\begin{array}{l}1 \\
1 \\
1 \\
1 \\
1 \\
1 \\
2 \\
1\end{array}$ & $\begin{array}{l}-- \\
-- \\
1 \\
-- \\
1 \\
-- \\
- \\
--\end{array}$ \\
\hline Current account & $\begin{array}{l}\text { real exchange rate } \\
\text { current account balance } \\
\text { trade balance } \\
\text { exports } \\
\text { imports } 1 / \\
\text { terms of trade } \\
\text { export prices } \\
\text { savings } \\
\text { investment }\end{array}$ & $\begin{array}{l}12 \\
6 \\
3 \\
3 \\
2 \\
2 \\
1 \\
1 \\
1\end{array}$ & $\begin{array}{l}10 \\
2 \\
2 \\
2 \\
1 \\
1 \\
-- \\
-- \\
--\end{array}$ \\
\hline International & $\begin{array}{l}\text { foreign real GDP growth } \\
\text { foreign interest rates } \\
\text { foreign price level }\end{array}$ & $\begin{array}{l}1 \\
3 \\
2\end{array}$ & $\begin{array}{l}-- \\
1\end{array}$ \\
\hline Financial liberalization & $\begin{array}{l}\text { real interest rates } \\
\text { credit growth } \\
\text { lending-deficit interest spread } \\
\text { money multiplier }\end{array}$ & $\begin{array}{l}1 \\
7 \\
1 \\
1\end{array}$ & $\begin{array}{l}1 \\
5 \\
-- \\
1\end{array}$ \\
\hline Other financial & $\begin{array}{l}\text { parallel market premium } \\
\text { central parity } \\
\text { position within the band } \\
\text { money demand-supply gap } \\
\text { change in bank deposits } \\
\text { central bank credit to banks } \\
\text { money } \\
\text { M2/international reserves }\end{array}$ & $\begin{array}{l}1 \\
1 \\
1 \\
1 \\
1 \\
1 \\
3 \\
2\end{array}$ & $\begin{array}{l}1 \\
1 \\
1 \\
1 \\
-- \\
1 \\
2 \\
2\end{array}$ \\
\hline Real sector ' & $\begin{array}{l}\text { inflation } 2 / \\
\text { rèal GDP growth'or level } \\
\text { output gap } \\
\text { employment/unemployment } 3 / \\
\text { change in stock prices }\end{array}$ & $\begin{array}{l}5 \\
8 \\
1 \\
3 \\
1\end{array}$ & $\begin{array}{l}5 \\
5 \\
1 \\
2 \\
1\end{array}$ \\
\hline
\end{tabular}


Table 4. Performance of Indicators (concluded)

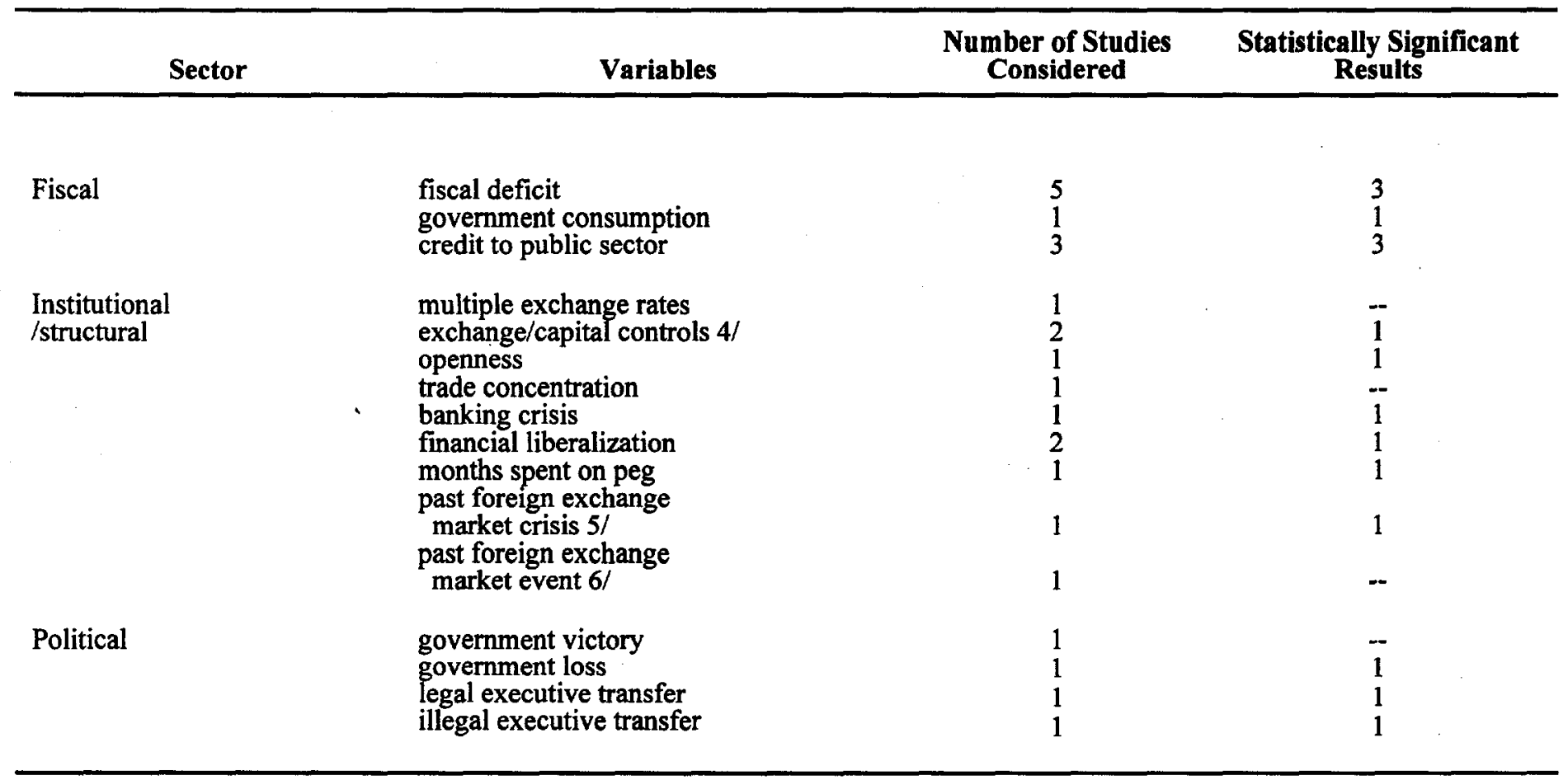

1/ In the statistically significant results, the rate of growth of imports declines prior to a devaluation.

$2 /$ In one of the statistically significant results, an increase in inflation reduces the probability of an attack.

3 / In one of the statistically significant results, an increase in employment increases the probability of an unsuccessful attack.

4/ In the statistical significant result, the presence of capital controls increases the probability of an unsuccessful attack and reduces the probability of a successful attack.

5/ A past foreign exchange market crisis reduces significantly the possibility of an unsuccessful attack, and increases marginally the possibility of a successful one.

6/ Events include significant changes in exchange arrangements (such as devaluations, revaluations, decisions to float, and widening of exchange rate bands); crises overlap with events but include unsuccessful speculative attacks and excludes changes in exchange arrangements not associated with market pressure. 
Table 5. "Signals" Approach. Performance of Indicators

\begin{tabular}{|c|c|c|c|c|c|c|c|}
\hline & $\begin{array}{l}\text { Number of } \\
\text { Crises for which } \\
\text { there are Data } \\
\text { (1) }\end{array}$ & $\begin{array}{l}\text { Percentage of } \\
\text { Crisis Called } \\
1 / \\
\text { (2) }\end{array}$ & $\begin{array}{c}\text { Good Signals } \\
\text { as Percentage } \\
\text { of Possible } \\
\text { Good Signals } \\
\text { (3) }\end{array}$ & $\begin{array}{c}\text { Bad Signals as } \\
\text { Percentage of } \\
\text { Possible Bad } \\
\text { Signals } \\
\text { (4) }\end{array}$ & $\begin{array}{l}\text { Noise/Signal } \\
\text { (adjusted) } 2 /\end{array}$ & P(Crisis/Signal)3/ & $\begin{array}{c}\mathrm{P}(\text { Crisis/Signal) } \\
-\mathrm{P}(\text { Crisis }) 4 / \\
\text { (7) }\end{array}$ \\
\hline $\begin{array}{l}\text { In terms of the matrix in } \\
\text { the text }\end{array}$ & & & $A /(A+C)$ & $\mathrm{B} /(\mathrm{B}+\mathrm{D})$ & $\begin{array}{l}{[\mathrm{B} /(\mathrm{B}+\mathrm{D})] /} \\
{[\mathrm{A} /(\mathrm{A}+\mathrm{C})]}\end{array}$ & $A /(A+B)$ & \\
\hline Real exchange rate & 72 & 57 & 25 & 5 & 0.19 & 67 & 39 \\
\hline Stock prices & 53 & 64 & 17 & 8 & 0.47 & 49 & 18 \\
\hline M2/international reserves & 70 & 80 & 21 & 10 & 0.48 & 46 & 17 \\
\hline Output & 57 & 77 & 16 & 8 & 0.52 & 49 & 16 \\
\hline "Excess" M1 balances & 66 & 61 & 16 & 8 & 0.52 & 43 & 15 \\
\hline Real interest rate & 44 & 89 & 15 & 11 & 0.77 & 34 & 6 \\
\hline Terms of trade & 58 & 79 & 19 & 15 & 0.77 & 36 & 6 \\
\hline Real interest differential & 42 & 86 & 11 & 11 & 0.99 & 29 & 0 \\
\hline Imports & 71 & 54 & 9 & 11 & 1.16 & 26 & -3 \\
\hline Bank deposits & 69 & 49 & 16 & 19 & 1.20 & 25 & -4 \\
\hline Lending rate/deposit rate & 33 & 67 & 13 & 22 & 1.69 & 18 & -9 \\
\hline
\end{tabular}

1/ Percentage of crises in which the indicator issued at least one signal in the previous 24 months, out of the total number of crises for which data are available.

2/ Ratio of false signals (measured as a proportion of months in which false signals could have been issued) to good signals (measured as a proportion of months in which

good signals could have been issued).

4/ $\mathrm{P}($ Crisis $)$ is the unconditional probability of a crisis, $(A+C) /(A+B+C+D)$ in terms of the matrix in the text. This probability ranges from 27 percent to 33 percent depending on the indicator. The unconditional probability varies across indicators because not all of them have observatories for the same jeriod. 
Table 6. Average Lead Time

\begin{tabular}{lc}
\hline \multicolumn{1}{c}{ Indicator } & $\begin{array}{c}\text { Number of Months in Advance of } \\
\text { the Crisis When First Signal Occurs }\end{array}$ \\
\hline Real exchange rate & 17 \\
Real interest rate & 17 \\
Imports & 16 \\
M2 multiplier & 16 \\
Output & 16 \\
Bank deposits & 15 \\
"Excess" M1 balances & 15 \\
Exports & 15 \\
Terms of Trade & 15 \\
International reserves & 15 \\
Stock prices & 14 \\
Real interest differential & 14 \\
M2/international reserves & 13 \\
Lending rate/deposit rate & 13 \\
Domestic credit/GDP & 12 \\
\hline
\end{tabular}


Table 7. Persistence of Signals

\begin{tabular}{lc}
\hline \multicolumn{1}{c}{ Indicator } & $\begin{array}{c}\text { Persistence During Crises Relative } \\
\text { to Tranquil Times }\end{array}$ \\
\hline Real exchange rate & 5.14 \\
Exports & 2.37 \\
Stock prices & 2.15 \\
M2/international reserves & 2.07 \\
Output & 1.93 \\
"Excess" MI balances & 1.92 \\
International reserves & 1.82 \\
M2 Multiplier & 1.64 \\
Domestic credit/GDP & 1.62 \\
Real interest rate & 1.30 \\
Terms of trade & 1.29 \\
Real interest differential & 1.01 \\
Imports & 0.86 \\
Bank deposits & 0.84 \\
Lending rate/deposit rate & 0.59 \\
\hline
\end{tabular}




\section{References}

Agenor, Pierre-Richard, Jagdeep S. Bhandari, and Robert P. Flood, "Speculative Attacks and Models of Balance of Payments Crises," Staff Papers, International Monetary Fund, Vol. 39 (June 1992), pp. 357-94.

Bilson, John F. O., "Leading Indicators of Currency Devaluations," Columbia Journal of World Business, Vol. 14 (Winter 1979), pp. 62-76.

Blackburn, Keith, and Martin Sola, "Speculative Currency Attacks and Balance of Payments Crises," Journal of Economic Surveys, Vol. 7 (June 1993), pp. 119-44.

Blanco, Herminio, and Peter M. Garber, "Recurrent Devaluation and Speculative Attacks on the Mexican Peso," Journal of Political Economy, Vol. 94 (February 1986), pp. 148-66.

Calvo, Guillermo A., "Varieties of Capital-Market Crises," Center for International Economics Working Paper No. 15 (College Park: University of Maryland, November 1995). , and Enrique Mendoza, "Reflections on Mexico's Balance-of-Payments Crisis: A Chronicle of A Death Foretold," (unpublished; College Park: University of Maryland, 1995).

Calvo, Sara, and Carmen M. Reinhart, "Capital Flows to Latin America: Is There Evidence of Contagion Effects?," in Private Capital Flows to Emerging Markets After the Mexican Crisis, ed. by Guillermo A. Calvo, Morris Goldstein, and Eduard Hochreiter (Washington: Institute for International Economics, 1996), pp. 151-71.

Collins, Susan M., "The Timing of Exchange Rate Adjustment in Developing Countries," (unpublished; Washington: Georgetown University, 1995).

Cumby, Robert, and Sweder van Wijnbergen, "Financial Policy and Speculative Runs with a Crawling Peg: Argentina 1979-81;" Journal of International Economics, Vol. 17 (August 1989), pp. 111-27.

Dellas, Harris, and Alan Stockman, "Self-fulfilling Expectations, Speculative Attack, and Capital Controls," Journal of Money, Credit, and Banking, Vol. 25 (November 1993), pp. 721-30.

Dornbusch, Rudiger, Ilan Goldfajn, and Rodrigo O. Valdés, "Currency Crises and Collapses," Brookings Papers on Economic Activity, No. 2 (1995), pp. 219-95.

Edin, Per-Anders, and Anders Vredin, "Devaluation Risk in Target Zones: Evidence from the Nordic Countries," The Economic Journal, Vol. 103 (January 1993), pp. 161-75.

Edwards, Sebastian, Real Exchange Rates, Devaluation, and Adjustment: Exchange Rate Policy in Developing Countries (Cambridge, Massachusetts: MIT Press, 1989). 
and Peter J. Montiel, "Devaluation Crises and the Macroeconomic Consequences of Postponed Adjustment in Developing Countries," Staff Papers, International Monetary Fund, Vol. 36 (December 1989), pp. 875-903.

, and Julio Santaella, "Devaluation Controversies in the Developing Countries: Lessons from the Bretton Wood Era," in A Retrospective on the Bretton Woods System: Lessons for International Monetary Reform, ed. by Michael D. Bordo and Barry Eichengreen (Chicago: University of Chicago Press, 1993), pp. 405-55.

Eichengreen, Barry, Andrew Rose, and Charles Wyplosz, "Exchange Market Mayhem: The Antecedents and Aftermath of Speculative Attacks," Economic Policy, Vol. 21 (October 1995), pp. 249-312.

Flood, Robert P., and Nancy Marion, "The Size and Timing of Devaluations in CapitalControlled Economies," (unpublished; Washington: International Monetary Fund, 1995).

Frankel, Jeff and Andrew Rose, "Currency Crashes in Emerging Markets: An Empirical Treatment," International Finance Discussion Paper No. 534 (Washington: Board of Governors of the Federal Reserve, January 1996).

Garber, Peter M., and Lars E. O. Svensson, "The Operation and Collapse of Fixed Exchange Rate Regimes," NBER Working Paper No. 4971 (Cambridge, Massachusetts: National Bureau of Economic Research, December 1994).

Gerlach, Stefan, and Frank Smets, "Contagious Speculative Attacks," CEPR Discussion Paper No. 1055 (London: Center for Economic Policy Research, November 1994).

Goldstein, Morris, "Presumptive Indicators/Early Warning Signals of Vulnerability to Financial Crises in Emerging Market Economies," (unpublished; Washington: Institute for International Economics, 1996).

Gupta, Poonam, "Currency Crises, Banking Crises and Twin Crises: A Comprehensive Review of the Literature," (unpublished; Washington: International Monetary Fund, 1996).

Humberto, Juan M. Julio, Santiago A. Herrera, "Crisis Cambiaria en un Sistema de Minidevaluaciones: El Caso de Colombia," Ensayos Sobre Politica Económica, Vol. 20 (1991), pp. 7-52.

Jeanne, Olivier, "Are Currency Crises Caused by the Fundamentals or by Self-Fulfilling Speculation? A Test," (unpublished; Paris: ENPC-CERAS, 1995).

Kamin, Steven B., "Devaluation, External Balance, and Macroeconomic Performance: A Look at the Numbers," Studies in International Finance, No. 62 (Princeton: Princeton University, Department of Economics, International Finance Section, August 1988). 
Kaminsky, Graciela, and Leonardo Leiderman, "High Real Interest Rates in the Aftermath of Disinflation: Credit Crunch or Credibility Crisis?," (unpublished; Washington: Board of Governors of the Federal Reserve, 1995).

, and Carmen M. Reinhart, "The Twin Crises: The Causes of Banking and Balance-ofPayments Problems," International Finance Discussion Paper No. 544 (Washington: Board of Governors of the Federal Reserve, March 1996).

Klein, Michael W., and Nancy Marion, "Explaining the Duration of Exchange-Rate Pegs," NBER Working Paper No. 4651 (Cambridge, Massachusetts: National Bureau of Economic Research, February 1994).

Krugman, Paul, "A Model of Balance of Payments Crises," Journal of Money, Credit, and Banking, Vol. 11 (August 1979), pp. 311-25.

, "Are Currency Crises Self-Fulfilling?," (unpublished; February 1996, prepared for the NBER Macro Annual Conference, March 8-9, 1996).

Milesi-Ferretti, Gian Maria, and Assaf Razin, "Current Account Sustainability," (unpublished; Washington: International Monetary Fund, 1995).

Moreno, Ramon, "Macroeconomic Behavior During Periods of Speculative Pressure or Realignment: Evidence from Pacific Basin Countries," Economic Review, Federal Reserve Bank of San Francisco, No. 3 (1995), pp. 3-16.

Obstfeld, Maurice, "Rational and Self-Fulfilling Balance-of-Payments Crises," The American Economic Review, Vol. 76 (March 1986), pp. 72-81.

,"The Logic of Currency Crises," NBER Working Paper No. 4640 (Cambridge, Massachusetts: National Bureau of Economic Research, February.1994).

"Models of Currency Crises With Self-fulfilling Features," European Economic Review, Vol. 40 (April 1996), pp. 1037-47.

Ötker, Inci and Ceyla Pazarbasioglu, "Exchange Market Pressures and Speculative Capital Flows in Selected European Countries," IMF Working Paper WP/94/21 (Washington: International Monetary Fund, February 1994). , and "Speculative Attacks and Currency Crises: The Mexican Experience," IMF Working Paper WP/95/112 (Washington: International Monetary Fund, November 1995).

Ozkan, F. Gulcin, and Alan Sutherland, "Policy Measures to Avoid a Currency Crisis," The Economic Journal, Vol. 105 (March 1995), pp. 510-19. 
Sachs, Jeffrey, Aaron Tornell and Andres Velasco, "Financial Crises in Emerging Markets: The Lessons From 1995," Brookings Papers on Economic Activity, No. 1 (1996), pp. 147-215.

Velasco, Andres, "Financial and Balance of Payments Crises: A Simple Model of the Southern Cone Experience," Journal of Development Economics, Vol. 27 (October 1987), pp. 263-83. 


\section{Policy Research Working Paper Series}

Title

WPS1828 The Determinants of Banking Crises:

Evidence from Developed and

Developing Countries

WPS1829 Economic Reform and progress in Latin America and the Caribbean

WPS1830 Private Ownership and Corporate Performance: Some Lessons from Transition Economies
Author

Asli Demirgüç-Kunt Enrica Detragiache

Norman Loayza

Luisa Palacios

Roman Frydman

Cheryl W. Gray

Marek Hessel

Andrzej Rapaczynski
WPS1832 Pension Reform in Bolivia: Innovative Hermann von Gersdorff Solutions to Common Problems

WPS1833 Cost Recovery and Pricing of

WPS1834 The Comparative Advantage of Payment Services Government: A Review

WPS1835 Cost-Benefit Analysis of the Global Aehyung Kim Dracunculiasis Eradication Campaign Ajay Tandon Ernesto Ruiz-Tiben

WPS1836 Heaith and Labor Productivity: The Economic Impact of Onchocercal Skin Disease

WPS1837 How Estonia's Economic Transition Affected Employment and Wages (1989-95)

David B. Humphrey

Robert H. Keppler

Fernando Montes-Negret

Pedro Belli

Aehyung Kim

Ajay Tandon

Asrat Hairu and Others

Rivo Noorkoiv

Peter F. Orazem

Allan Puur

Milan Vodopivec

WPS1838 The Limits and Merits of Participation Paulo Vieira da Cunha

Maria Valeria Junho Pena

WPS1839 The Effects of Financial Liberalization Cevdet Denizer and New Bank Entry on Market Structure and Competition in Turkey

WPS1840 Efficient Public Sector Downsizing Martin Rama

WPS1841 Patterns of Metropolitan Development: What Have We Learned?
Date

September 1997

September 1997

September 1997

September 1997

September 1997

Contact

for paper

P. Sintim-Aboagye 38526

E. Khine 37471

B. Moore 38526

J. Ngaine 37947

C. Pavlak 82099

October 1997

$T$. Ishibe 38968

October 1997

L. Schunk 31779

October 1997

A. Kim 35029

October 1997

A. Kim 35029

October 1997

S. Fallon 38009

October 1997

E. Thomas 31019

November 1997

E. Khine 37471

November 1997

S. Fallon 38009

November 1997

J. Ponchamni 31052 


\section{Policy Research Working Paper Series}

Title

WPS1842 Motorization and the Provision of Roads in Countries and Cities

WPS1843 Externalities and Bailouts: Hard and Soft Budget Constraints in Intergovernmental Fiscal Relations

WPS1844 Child Labor and Schooling in Ghana

WPS1845 Employment, Labor Markets, and Poverty in Ghana: A Study of Changes during Economic Decline and Recovery

WPS1846 Africa's Role in Multilateral Trade Negotiations

WPS1847 Outsiders and Regional Trade Agreements among Small Countries: The Case of Regional Markets

WPS1848 Regional Integration and Commodity Tax Harmonization

WPS1849 Regional Integration and Factor Income Taxation

WPS1850 Determinants of Intra-Industry Trade between East and West Europe

WPS1851 Transportation Infrastructure Investments and Regional Trade Liberalization
Author

Date

Gregory K. Ingram

Zhi Liu

David E. Wildasin

Sudharshan Canagarajah

Harold Coulombe

Sudharshan Canagarajah

Dipak Mazumdar

November 1997

Zhen Kun Wang

L. Alan Winters

Anju Gupta

Valeria De Bonis

Valeria De Bonis

Contact

for paper

November 1997

November 1997

November 1997

B. Casely-Hayford 34672

B. Casely-Hayford 34672

November 1997 J. Ngaine 37947

November 1997 J. Ngaine 37947

November $1997 \quad J$. Ngaine 37947

November $1997 \quad$ J. Ngaine 37947

November $1997 \quad$ J. Ngaine 37947

Simeon Djankov Bernard Hoekman

Eric W. Bond

November 1997

J. Ngaine 37947 